Linköping Studies in Science and Technology. Thesis No. 1806 Licentiate Thesis

\title{
Construction \\ Logistics Solutions in Urban Areas
}

Mats Janné 


\section{Construction Logistics Solutions in Urban Areas}

Mats Janné

Linköping Studies in Science and Technology. Licentiate Thesis No. 1806

Copyright C, Mats Janné, 2018, unless otherwise noted.

This is a Swedish Licentiate Thesis. The Licentiate degree comprises 120 ECTS credits of postgraduate studies.

ISBN 978-91-7685-290-3

ISSN 0280-7971

Linköping University

Department of Science and Technology

SE-601 74 Norrköping, Sweden

Printed by LiU-Tryck, Linköping, Sweden, 2018 


\section{Abstract}

More and more people are living in, or moving to, urban areas than ever before. This attraction to urban areas means that new houses and workplaces are needed. Building new houses or renovating older housing stock is a natural way for a city to evolve. However, the end products of construction projects are produced at their place of consumption. This means that a multitude of materials and resources need to be delivered to, and removed from, each construction site. This leads to new transport flows being created in urban areas. In urban areas, these transports are subjected to space limitations, environmental demands, accessibility demands and noise restrictions. This has led to a situation where material deliveries to construction sites needs to be coordinated and managed in ways that reduce their impact on the urban transport system and at the same time ensuring efficient construction projects.

In essence, construction in urban areas faces two problems; the urban transport problem and the problem of coordinating multiple construction stakeholders. One way to address these problems is through the use of construction logistics solutions such as terminals (e.g. construction logistics centres) and checkpoints. The aim of both types of solutions is to control and coordinate construction transports. In the construction industry, these solutions are however, still a rather new phenomenon. This means that how these solutions are perceived by different stakeholders, and the effect the solutions have on material flows and costs, needs to be explored further.

The purpose of this thesis is to explore how construction logistics solutions can be used as a means to coordinate material flows to ensure efficient construction and reduce disturbances on the urban transport system. To achieve this purpose, the following research questions have been addressed:

RQ1: How are different stakeholders in the construction industry affected by construction logistics solutions?

RQ2: How will the use of construction logistics solutions affect material flows and costs in urban construction projects?

To answer the research questions two main methodologies have been used; case study research for the empirical studies and literature reviews for the analysis of the case studies as well as for understanding how supply chain management, logistics, and third-party logistics affects the inter-organizational relationships of the construction industry. 
The main findings of the research are firstly that construction logistics solutions do have a role to play in the coordination of different construction stakeholders. Adding this new node will force construction stakeholders to address coordination issues in order to ensure that material deliveries arrive to construction sites on time. This also implies that new interorganizational relationships will evolve, where communication is key. However, this may not be an easy task as it will call for an attitude adjustment towards a more open and collaborative environment.

Secondly, adding a construction logistics solution can reduce some unnecessary friction between construction stakeholders and third parties. Coordinated material flows can lead to a reduction in the amount of material delivery vehicles that travels to site, thus alleviating some of the congestion in the urban transport system. This will not reduce all friction between construction projects and third parties, but it is a step in the right direction.

Thirdly, a construction logistics solution must come with a set of regulations and a governance strategy from the initiator of the solution. This governance strategy must be clearly stated and communicated to the affected stakeholders. To alleviate animosity towards the solution, flexibility and stakeholder involvement is key. If the directly affected stakeholders are consulted on the function, chances are that they will be more accepting of the solution. 


\section{Populärvetenskaplig sammanfattning}

Fler människor lever i eller flyttar till städer och urbana områden än någonsin tidigare. Denna dragning till städer innebär ökade behov av hus och arbetsplatser. Att bygga nya hus eller renovera äldre bostadsbestånd är ett naturligt sätt för en stad att utvecklas. Dock karaktäriseras byggprojekt av att slutprodukten produceras på dess konsumtionsplats. Det innebär att stora mängder material och resurser måste levereras till och forslas bort från varje byggarbetsplats. Detta leder i sin tur till att nya transportflöden skapas i städerna.

Byggtransporter utgör cirka 20 procent av allt godstransportarbete i Sverige. I städerna påverkas dessa transporter av utrymmesbegränsningar, miljökrav, tillgänglighetskrav och bullerbegränsningar. Detta innebär att materialleveranser till byggarbetsplatser måste samordnas och hanteras på ett sätt som minskar deras inverkan på tredje part samtidigt som de säkerställer effektiva byggprojekt. Detta leder till att byggindustrin står inför två problem i stadsområden; problemet med stadstransport och problemet med att koordinera byggaktörer. Ett sätt att hantera dessa problem är genom användningen av bygglogistiklösningar såsom terminaler (bygglogistikcenter) och checkpoints. Målet för båda typerna av lösningar är att styra och samordna byggtransporter. I byggbranschen är dessa lösningar dock ett relativt nytt och outnyttjat fenomen. Det innebär att hur dessa lösningar uppfattas av olika intressenter och vilken effekt lösningarna har på materialflöden och kostnader behöver undersökas ytterligare.

Forskningen som presenteras i den här avhandlingen har syftat till att undersöka hur bygglogistiklösningar kan användas för att samordna byggaktörer och materialflöden till byggarbetsplatser samt hur man kan styra stadstransporter för att säkerställa effektivt byggande och minska störningarna mot tredje part. Forskningen har bedrivits genom att bland annat studera bygglogistikcenter i Norra Djurgårdsstaden samt ett stort kontorsbyggnadsprojekt i Solna där en liknande bygglogistikcenterlösning har använts.

Forskningsresultaten visar på att bygglogistiklösningar har en roll att spela i samordningen av olika byggaktörer. Den nya noden som läggs till tvingar byggaktörer att ta itu med samordningsfrågor för att säkerställa att materialleveranser når fram till byggarbetsplatser i tid. Detta innebär också att nya interorganisatoriska relationer kommer att uppstå, där kommunikation är en nyckelfaktor.

En bygglogistiklösning kan också minska onödig friktion mellan byggaktörer och tredje part. Koordinerade materialflöden kan leda till en minskning av mängden fordon som färdas till byggarbetsplatsen och därigenom minska trafikstockningarna i det urbana transportsystemet. 
Slutligen visar forskningen på att en bygglogistiklösning måste introduceras med en uppsättning bestämmelser och en styrstrategi från den som initierar lösningen. Dessa bestämmelser och styrmedel måste vara tydliga och kommuniceras till berörda aktörer. För att minska motsättningar mot lösningen måste flexibilitet och intressentengagemang vara ledord. Om de direkt berörda aktörerna konsulteras om hur lösningen ska fungera ökar chansen att de kommer att acceptera lösningen. 


\section{Foreword}

This journey that I am on, chasing that illusive $\mathrm{PhD}$, is something that I have wanted to embark on for such a long time. Being here now, halfway through the PhD process, is something that would not have been possible without the support of the people around me. These few humble lines are dedicated to those persons.

First and foremost, I want to thank my amazing superhero supervisor team, Martin Rudberg and Anna Fredriksson. Working with the two of you is a pleasure, I could not have asked for better people to guide me through this journey. I honestly do not think that this thesis would have turned out as well as it did without your scrutineering and support.

Secondly, I want to give my special thanks to my colleagues in the construction logistics group, past and present, Andreas Ekeskär, Henric Jonsson, and Micael Thunberg. You are more than just colleagues to me, you are my dear friends. I cannot thank you enough for all the laughter, and occasional serious discussions we have had through the years. Thank you also for taking the time to read and comment on this thesis.

Thirdly, I want to thank all my colleagues at the division of Communications and Transport Systems, this place would not be the same without you. A special thank you to Viveka Nilsson, your help with, well, everything is invaluable. I promise to (try to) become better at handing in my travel orders on time. :)

Finally, my thanks (and love) go out to my friends and family. I know that you may not always understand why I spend most of my time working or taking photos of cranes and construction sites, but you know that it is important to me and you always back me up in my shenanigans or force me to take a break when you see that I need it (even though I rarely want to). Thank you!

Mats Janné

Jursla, April 2018 


\section{Acknowledgement}

There are a number of people that have contributed to this research that I wish to thank. I am very grateful to Sandra Lasson, Ronny Strigell, Johan Reichelt, Fredrik Bergman, Robin Billsjö, Anders Ivarsson, Abdinasir Osman, Daniel Eriksson, Per Bramfalk, Camilla Einarsson, Johan Danielsson, Arvid Westin, Rasmus Linge, Jihad Ghaziri, Tommie Valkeaniemi, Björn Ribbhagen, Christer Källström, Malin Lindskog, Monica Billger, Kajsa Hulthén, Maria Oscott, Lovisa Westblom, Eric Sens, Michael Berden, Marie Morel, Susanne Balm, Walther Ploos van Amstel, Pamela Nolz, Tom van Lier, Robert Larsson, and Antti Peltokorpi. Thank you all for great discussions and input to the research project. I would also like to extend my gratitude to the Development Fund of the Swedish Construction Industry SBUF, as well as Sweden's Innovation Agency VINNOVA/JPI Urban Europe, for financing this research. 


\section{Thesis outline}

This licentiate thesis is of a compilation character (thesis by publication), comprising four articles; one under review in Construction Innovation, and two working papers being developed from their previous conference paper versions. The final paper is to be presented at the $30^{\text {th }}$ NOFOMA conference in Kolding, DK. The thesis is titled Construction logistics solutions in urban areas and consists of two parts. The introductory chapters in this thesis set out to describe the background to why the work is deemed necessary, together with the purpose and research objectives. It will also guide the reader in the current literature and what each paper in the thesis concerns. Finally, the first part will answer the research questions and present the conclusions. It will also pinpoint the contributions and present ideas on future research. The second part consists of the four papers that the research rests upon. These are listed below.

\section{Paper 1}

Janné, M. (2018). "Supply chain management, logistics, and third-party logistics in Construction - A literature review". Working paper. Previously presented as a conference paper at the $3^{\text {rd }}$ VREF Conference on Urban Freight in 2016.

\section{Paper 2}

Janné, M. and Fredriksson, A. (2018). "Construction logistics solutions in city development projects". Under review in Construction Innovation. Previously presented as a conference paper at the $29^{\text {th }}$ annual NOFOMA Conference in 2017.

\section{Paper 3}

Janné, M. and Rudberg, M. (2017). "Costs and benefits of logistics solutions in construction". Working paper. Previously presented as a conference paper at the $24^{\text {th }}$ annual EurOMA Conference in 2017.

\section{Paper 4}

Janné, M. and Fredriksson, A. (2018). "Cost modelling construction logistics centres". Conference paper. To be presented at the $30^{\text {th }}$ annual NOFOMA Conference in 2018. 
"The difficulty lies not so much in developing new ideas as in escaping from old ones."

- John Maynard Keynes (1936) 


\section{Table of contents}

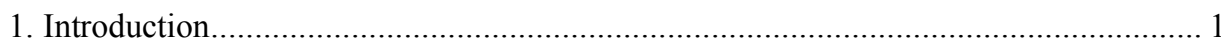

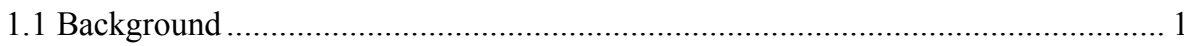

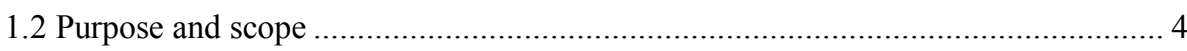

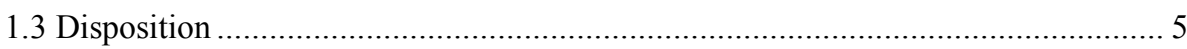

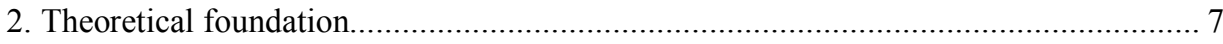



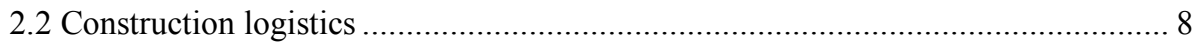

2.2.1 The urban transport problem ................................................................. 9



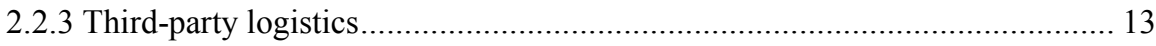





2.3.1 Control mechanisms and governance enablers........................................ 16

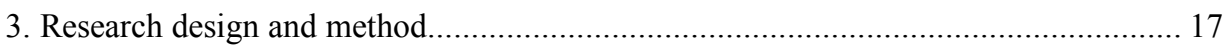

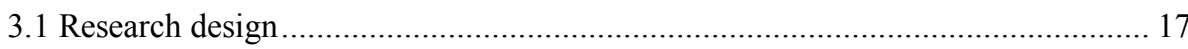





3.3.1 Analytical research through literature reviews and conceptual modelling ...... 19

3.3.2 Empirical research through case studies .................................................. 20

3.3.3 Paper 1 - Understanding logistics issues in the construction supply chain...... 21

3.3.4 Paper 2 - Experiences of construction logistics centres in urban development 23

3.3.5 Paper 3 - Finding cost effects and benefits of construction logistics solutions 24

3.3.6 Paper 4 - Determining the cost of construction logistics centres ................... 26

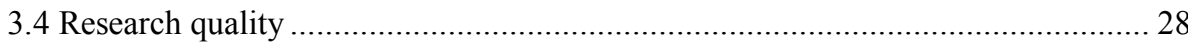

3.4.1 Research quality in content analysis-based literature reviews ..................... 28

3.4.2 Research quality in case study research................................................... 31

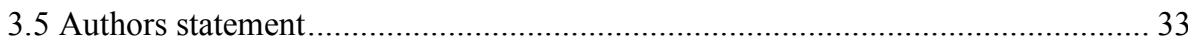



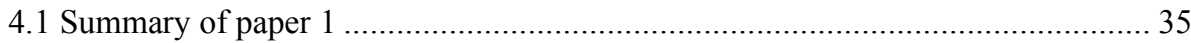




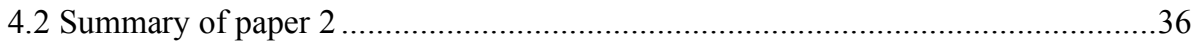

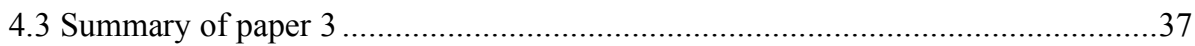

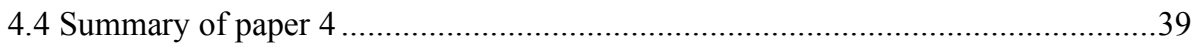

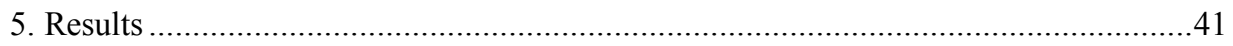

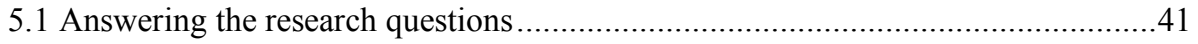

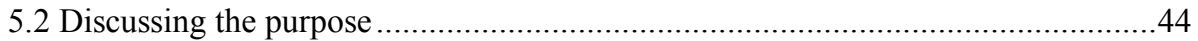

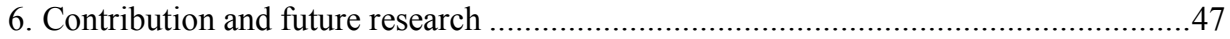



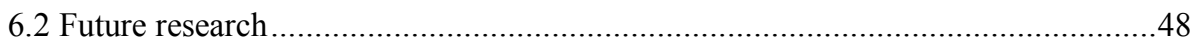

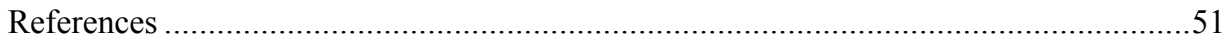

Paper 1 - Supply chain management, logistics, and third-party logistics in construction - A literature review

Paper 2 - Construction logistics solutions in city development projects

Paper 3 - Costs and benefits of logistics solutions in construction

Paper 4 - Cost modelling construction logistics centres

\section{List of figures and tables}

Figure 1 - Material flows in urban areas are subjected to the urban transport problem ......2

Figure 2 - The construction industry structure of tight and loose couplings........................

Figure 3 - Coordinating and controlling the urban transport problem and construction industry issues through construction logistics solutions ..............................................



Figure 5 - The functionality of construction logistics centres........................................ 11

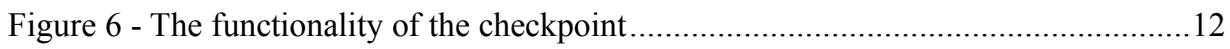

Figure 7 - Relation between research design, research questions, and research scope .....17



Figure 9 - A continuum of literature review research approaches (Jesson, et al., 2011, p. 11)








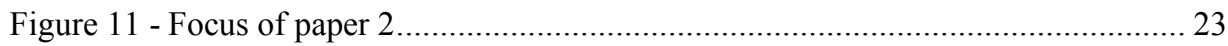

Figure 12 - The logistics processes studied in paper 2 2................................................ 24



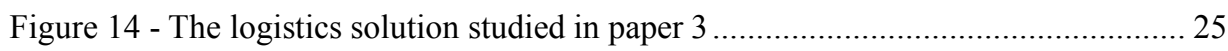

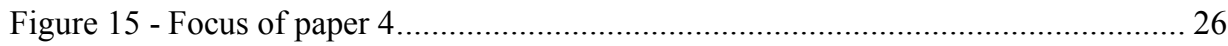

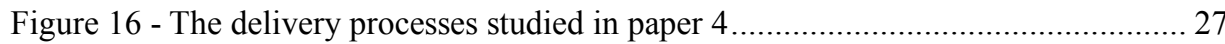

Table 2 - Milestones for content analysis in literature reviews (Seuring and Gold, 2012, p.

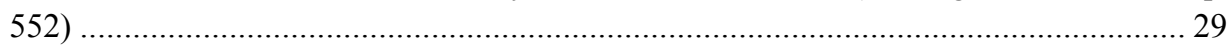

Table 3 - Means to ensure research quality (Yin, 2014, p. 45)..................................... 31

Figure 17 - The stakeholder experiences of utilizing a CLC...................................... 37

Table 4 - The identification of benefits, issues, and cost effects of CLS's...................... 38

Table 5 - Identified activities and resources in the material delivery process using a CLC 40

Figure 18 - ABC breakdown of utilizing a CLC …................................................. 44 


\section{Introduction}

In this chapter, the underlying problems that motivate this doctoral research project are described. The purpose of the project is presented alongside the research questions in focus and the research scope.

\subsection{Background}

This research is part of a doctoral research project focusing on construction logistics solutions (CLS's) and their role in governing and coordinating material flows and stakeholders in urban development projects. This licentiate thesis seeks to highlight how a CLS can ensure efficient material flows to construction sites and reduce disturbances within the urban transport system.

The reason for focusing on construction in urban areas is the on-going urbanisation trend. In 2007 the global urban population exceeded the rural population for the first time in history (United Nations, 2015, p. 7). In Europe, approximately 75 per cent of the population was living in urban areas in 2014, and in Sweden the corresponding figure was 85,8 per cent (United Nations, 2015, p. 209). The urban population in Sweden is predicted to rise to 90,3 per cent by 2050 (United Nations, 2015, p. 209). This attraction to cities and urban areas means that new houses, apartment buildings, office complexes, hospitals, schools and infrastructure need to be constructed. Building new houses or renovating older housing stock is a natural way for a city to evolve. However, construction projects are producing the end product (houses or infrastructure) at the place of consumption (cf. Ekeskär and Rudberg, 2016), meaning that a multitude of materials and resources need to be delivered to, and removed from, each site at the correct time (cf. Josephson and Saukkoriipi, 2007; Lindén and Josephson, 2013). This leads to additional transport flows being created, competing for the existing infrastructure with other traffic users.

Construction transports represent approximately 20 per cent of all goods kilometres driven in Sweden (Sveriges Byggindustrier, 2010). In urban areas, these transports are subjected to the urban transport problem, i.e. space limitations, municipal demands to reduce environmental impact, as well as demands from residents and shop-owners on accessibility and noise restrictions (Carlsson and Janné, 2012; Dablanc, 2007). This implies that material deliveries to construction sites need to be coordinated and managed in a way that reduces their impact on the urban transport system, while at the same time ensuring that construction can proceed without reduced efficiency on site due to missed or delayed material deliveries. Figure 1 schematically positions the material flow of construction logistics within the urban transport system. 


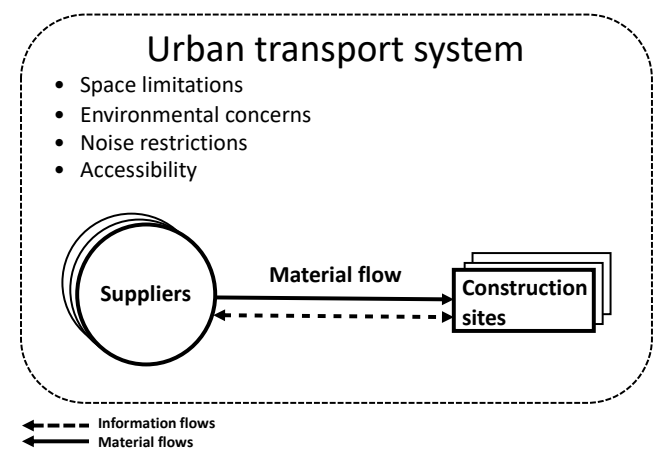

Figure 1 - Material flows in urban areas are subjected to the urban transport problem

Adding to the transport related coordination problems of urban construction, is the interorganizational relationships within the construction industry itself. Construction in general is produced on a project basis in temporary organizations, where the project organizations often become disconnected from the company level and hard to manage and integrate (Dubois and Gadde, 2000, 2002; Karrbom Gustavsson and Gohary, 2012; Karrbom Gustavsson and Hallin, 2015). Dubois and Gadde (2002) argue that within construction projects, the couplings between different stakeholders and activities on-site are characterized as tight, meaning that within a project each stakeholder and activity is dependent on one another. At the same time, the construction projects are managed from the project organization and the parent company has little control over the everyday operations of the project, i.e. the couplings between parent companies and construction projects are loose (Dubois and Gadde, 2002). The tight and loose couplings are illustrated in Figure 2. The temporary nature of construction projects also means that different contractors, sub-contractors, consultants and builders' merchants need to be tendered and procured every time a new construction project is launched (Dubois and Gadde, 2000, 2002; Kristiansen, et al., 2005). Dubois and Gadde (2000) highlight that as much as 75 per cent of the product value is added by sub-contractors and suppliers. With the temporary nature in mind, the industry has struggled to find good forms of long-term collaborative relationships (Fernie and Thorpe, 2007; Green, et al., 2005; Kristiansen, et al., 2005). Instead adversarial contracts and arm's length relationships seem to be the preferred way of managing relationships (Fernie and Thorpe, 2007; Green, et al., 2005; Kristiansen, et al., 2005). This of course also affects how logistics and material deliveries are managed. Different stakeholders can e.g. place different demands and considerations on how construction logistics is to be carried out. Managing projects under these complex conditions is difficult due to high levels of uncertainty, as well as a mixture of organizations (Locatelli, et al., 2014). 


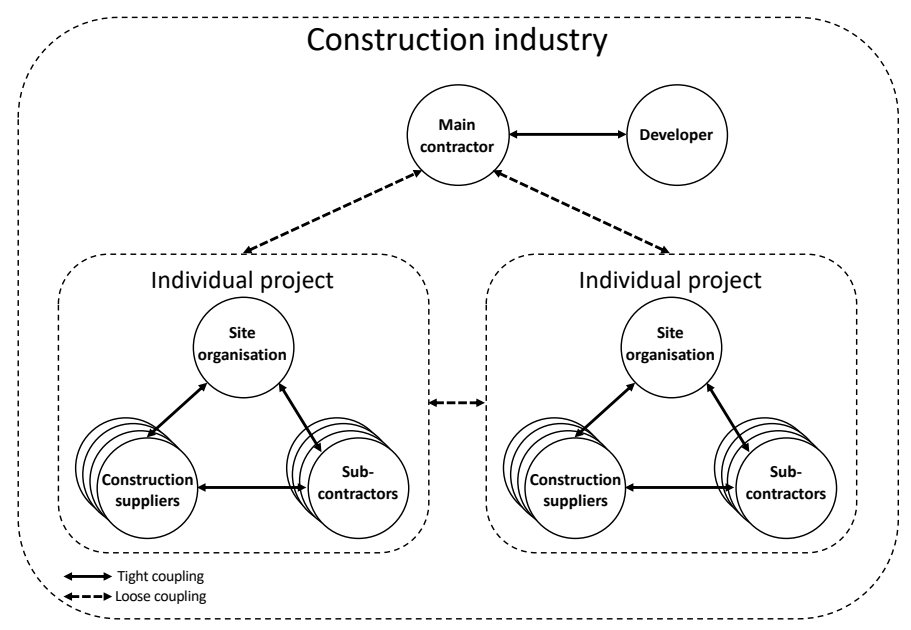

Figure 2 - The construction industry structure of tight and loose couplings

In essence, construction in urban areas faces two problems; the urban transport problem and the problem of coordinating multiple construction stakeholders (see Figure 3). One way to address these problems is through the use of CLS's such as terminals (e.g. construction logistics centres) and checkpoints. The aim of both types of solutions is to control and coordinate construction transports, but through different means. The aim of the construction logistics centre (CLC) is to consolidate goods, thus reducing traffic to site (cf. Hamzeh, et al., 2007; Transport for London, 2013), whereas the checkpoint aims at coordinating just-in-time (JIT) deliveries to site through planning efforts (cf. Ekeskär and Rudberg, 2016). Logistics solutions can be initiated and designed by different stakeholders; i.e. the developer (Ekeskär and Rudberg, 2016), the municipality (Transport for London, 2013), a main contractor (Lindén and Josephson, 2013), or the individual projects (Lindén and Josephson, 2013).



Figure 3 - Coordinating and controlling the urban transport problem and construction industry issues through construction logistics solutions 
Previous research has focused on the effect of CLS's or third-party logistics (TPL) in construction from either a supply chain management (SCM) perspective (cf. Ekeskär, 2016), the effect that these concepts have on the construction site (cf. Lindén and Josephson, 2013), or from a city logistics perspective (cf. Transport for London, 2013). In the construction industry, these solutions are still a rather rare phenomenon (cf. Langley, 2016; Ekeskär, 2016), especially when proposed as joint solution for multiple construction stakeholders and projects. The rarity of these solutions indicates that there is a research gap in how these construction logistics solutions affect material flows and costs, as well as how they are perceived by different stakeholders. This research contributes by addressing both the urban transport problem and the coordination problem by investigating how CLS's can be used to coordinate material flows in urban construction logistics.

\subsection{Purpose and scope}

The purpose of this thesis is to explore how construction logistics solutions can be used as a means to coordinate material flows to ensure efficient construction and reduce disturbances on the urban transport system. To fulfil this purpose, the following research questions will be addressed:

RQ1: How are different stakeholders in the construction industry affected by construction logistics solutions?

RQ2: How will the use of construction logistics solutions affect material flows and costs in urban construction projects?

The scope of this research is on material deliveries in urban construction, the transport flows they generate, and the stakeholders affected by these transports. Specifically, the use of CLS's and how they affect construction material flows are in focus. This focus has been divided into two parts; the first part investigates what the coordination issues are in the construction industry and how construction logistics solutions can help in coordinating different construction stakeholders. This is studied through a literature review and one empirical study of a municipality initiated CLC. This part helps in answering research question 1.

The second part explores the effect CLS's can have on material flows in urban construction. This is studied through two empirical studies; one study of a contractor initiated CLC for a large office complex project, and one study of a municipality initiated CLC for a large urban development project. This part corresponds to research question 2 .

The unit of analysis in this thesis is the CLS and the effect it has on the main stakeholders connected to it. The context of the research is construction in the urban environment. To provide an understanding of how CLS's affect different stakeholders in urban areas, different stakeholder perspectives needs to be taken into account. Figure 4 shows the scope of the thesis and the primary stakeholders of urban construction, i.e. municipalities, developers, contractors, suppliers, and logistics service providers (represented by the CLS). 




Figure 4 - Scope of research

\subsection{Disposition}

The first chapter gives a brief introduction to the problems that have been studied in this research project and introduces the purpose and research questions of the project. To address the purpose and answer the research questions, a literature review has been carried out. This is presented as a theoretical foundation in chapter 2 . This licentiate thesis is the result of a three-year research project, the design and methodology of which is presented in chapter 3. This chapter also describes and motivates the entire research process and highlights how the different studies in the project are linked to one another. Chapter 4 summarizes the papers that this thesis is built upon and chapter 5 analyses them jointly to provide answers to the research questions of the thesis as well as fulfilling the thesis purpose. The contributions of the thesis are presented in chapter 6 alongside suggestions for future research. 


\section{Theoretical foundation}

This chapter sets out to describe the theoretical foundations on which this thesis rests. As described previously, the widespread utilization of CLS's is still in its infancy, and the understanding of these concepts is limited. To get to the heart of the utilization of CLS's, three theoretical areas needs to be considered; the construction industry context, construction logistics, and inter-organizational relationships and governance.

\subsection{Construction industry context}

One of the main characteristics of the industry is that it first and foremost is built around temporary organizations and relationships. Different contractors, sub-contractors, consultants, builders' merchants and logistics operators need to be tendered and procured every time a new construction project is launched, making long-term relationships difficult to achieve. As discussed by Dubois and Gadde (2000), the construction industry is characterized with high levels of resource dependency (cf. Penrose, 1959; Yuchtman and Seashore, 1967) and utilizes temporary network structures to ensure that this resource dependence can be met. Construction project organizations thus often become disconnected from the company level and hard to manage and integrate throughout the process, from drawings to finished building. (Dubois and Gadde, 2000, 2002; Karrbom Gustavsson and Gohary, 2012; Karrbom Gustavsson and Hallin, 2015; Kristiansen, et al., 2005; London and Kenley, 2001)

Dubois and Gadde (2002) characterizes the network structure of the construction industry as two-fold; the industry has tight relationship networks within the projects, and a much looser network structure between the parent companies and projects and between different construction stakeholders. This means that within a project each stakeholder and activity is dependent on one another. Activities often have to be performed in sequence and if one activity is delayed, all the following activities will also be delayed (Dubois and Gadde, 2002). Similarly, workers and installers need to have materials in place and if deliveries are delayed the whole project can be delayed. Thus, there is a need within the project environment for tight couplings between stakeholders in order to move the project forward at the established pace. At the same time, they acknowledge that the couplings between the project and company levels are loose. The construction projects are managed from the project organization and the parent company has little control over the everyday operations of the project (Dubois and Gadde, 2002). Within these network structures, the bigger stakeholders have bargaining power due to their size and central position, whereas smaller, more specialized stakeholders have bargaining power through their asset specificity (cf. Benson, 1975, p. 233). 
Even though one of the main criticisms towards the construction industry is an unwillingness to change, Kristiansen, et al. (2005) point out that the industry has in fact experienced substantial changes through mergers and acquisitions. Large main contractor companies have grown bigger and sub-contractors, suppliers and builders' merchants have had to adopt their business models in order to ensure a continued workload (Kristiansen, et al., 2005; Agapiou, et al., 1998b). Sub-contractors are specializing in certain business segments whereas builders' merchants and suppliers are entering international markets in order to increase their market segments (Kristiansen, et al., 2005; Agapiou, et al., 1998b). The specialists provide asset specificity to those who do not possess the sought-after assets themselves, and in doing so, they hold the bargaining power (cf. Wilkins and Ouchi, 1983; Williamson, 1979; Klein, et al., 1978; Zajac and Olsen, 1993; Boissinot and Paché, 2011). At the same time, the specialized sub-contractors and builders' merchants are also dependent on the large contractors for work. Overall, these tendencies have led to a fragmented industry where highly specialized companies are focused primarily on their own survival and cooperation amongst companies is at its best rare (Agapiou, et al., 1998b; Bankvall, et al., 2010; Dubois and Gadde, 2000, 2002; Fernie, et al., 2006; Fernie and Tennant, 2013; Fernie and Thorpe, 2007). This leads to a situation where adversarial contracts and arm's length contractual relations outweighs management of processes and relationships (Dubois and Gadde, 2002; Fernie and Tennant, 2013; Green, et al., 2005; Kristiansen, et al., 2005; Fernie and Thorpe, 2007).

The fragmentation of the industry is however, not only disadvantageous. Several researchers highlight that the fragmented nature of the construction industry also allows for great flexibility at the project level, allowing for local adaptations and problem solving, but also as a means to handle the complexity of the industry (Dubois and Gadde, 2000, 2002; Egan, 1998; Fernie, et al., 2006; Green, et al., 2005). At the same time, there is a call for the industry to move away from adversarial relationships towards more collaborative working practices and long-term commitment (Egan, 1998; Josephson and Saukkoriipi, 2007; Latham, 1994; Strategic Forum, 2002).

It is fair to assume that due to the industry structure and fragmentation mentioned, the contractors, sub-contractors, builders' merchants and logistics operators have their own view as to how to manage their respective trades and logistics setups, and even what their work entails. However, the sought-after coordination and collaboration with channel partners do not necessarily occur in this environment if not all partners are striving towards the same supply chain goals (Mentzer, et al., 2001). With the temporary nature of construction projects and temporary supply chains, long-term knowledge exchange from project to project is also difficult to achieve.

\subsection{Construction logistics}

The goal for any construction project is to deliver the project on time and on cost to the stipulated quality The construction industry is producing its end products (the house or infrastructure) from vast amount of materials that have to be delivered to the place of consumption (Ekeskär and Rudberg, 2016; Lindén and Josephson, 2013; Thunberg and 
Persson, 2014; Thunberg, et al., 2017). Thus, the construction industry is greatly dependent on materials arriving to site when needed (Josephson and Saukkoriipi, 2007; Lindén and Josephson, 2013). The process of managing these material flows is called logistics and can be defined as:

"Logistics is the process of strategically managing the procurement, movement and storage of materials, parts and finished inventory (and the related information flows) through the organization and its marketing channels in such a way that current and future profitability are maximized through the costeffective fulfilment of orders" (Christopher, 2011)

In a construction setting, this is referred to as construction logistics and can be defined as dealing with supplying the right materials to the correct customer and construction site to meet customers' requirements.

In urban construction areas, the urban context set limitations on how construction logistics can be carried out. The following sections presents the urban transport problem and how the construction industry can work to coordinate their material flows within the urban context through utilizing CLS's and third-party logistics. Finally, this section discusses the cost of logistics and how to analyse these.

\subsubsection{The urban transport problem}

Goods transports play an important role in the prosperity of the urban environment (cf. Anderson, et al., 2005; Bretzke, 2013; Lindholm, 2010), but they also affect the urban environment negatively (cf. Bretzke, 2013; Dablanc, 2007; Lindholm, 2010). Issues such as emissions, congestion, noise and accidents are frequently attributed to urban transport in general and urban goods transport in particular (cf. Anderson, et al., 2005; Behrends, et al., 2008; Bretzke, 2013; Dablanc, 2007, 2008). These issues impact the urban environment on social, economic and ecological levels (Anderson, et al., 2005). Emissions can cause numerous health problems and affect the quality of life for inhabitants (Dablanc, 2008) while at the same time contributing to global environmental impact through the emission of greenhouse gases (Anderson, et al., 2005). Economically, the costs incurred through congestion affects inhabitants as well as companies (Bretzke, 2013; Russo and Comi, 2010), and here in lies the main problem of the urban transport system; it is a complex transport system where goods and passengers utilize the same, limited infrastructure (Carlsson and Janné, 2012; Dablanc, 2007; Russo and Comi, 2010). Additionally, the transport system is populated by a combination of different vehicle types and road users, increasing the risk of accidents (Carlsson and Janné, 2012; Russo and Comi, 2010). This leads to the urban goods transport system not being as efficient as it could be (Lindholm, 2012). As noted, an efficient goods transport system is a necessity for the urban economy (Anderson, et al., 2005; Lindholm, 2012) and should be a priority for cities, inhabitants and companies alike (Lindholm, 2012).

Urban transport systems are subjected to a vast amount of regulations (Carlsson and Janné, 2012; Ballantyne, et al., 2013) regardless of if it is goods or people being transported. 
However, previous studies have noted that cities and authorities traditionally have not focused on strategies for urban goods transports or coordinating efforts among different urban transport stakeholders (Ballantyne, et al., 2013; Fossheim and Andersen, 2017; Lindholm, 2012). Goods transports and logistics has been treated as a problem for the logistics industry to solve (Ballantyne, et al., 2013). This lack of clarity and focus on goods transports adds to the complexity of the urban transport system.

\subsubsection{Construction logistics solutions}

As noted earlier, approximately a fifth of all goods transports in Sweden deliver materials to and from construction sites (Sveriges Byggindustrier, 2010). With the ongoing urbanisation trend, this means that a large proportion of these transports take place in the complex urban transport system. To manage the material deliveries to these urban construction sites, there is a need to improve how construction logistics is controlled, coordinated and executed. Agapiou, et al. (1998a) highlight that the focus of any construction logistics setup must be to improve coordination and communication between project stakeholders, and that the solution must be designed from a holistic view to create the best possible material flows to and from site. A construction logistics solution can range from just a small change in working practices (Aguirre, et al., 2010; Gajendran, et al., 2013; Perttula, et al., 2006; Tanskanen, et al., 2015), implementing planning systems and ICT tools (Fadiya, et al., 2015; Hadaya and Pellerin, 2010; Titus and Bröchner, 2005), to largescale terminal networks structures (Lundesjo, 2011; Transport for London, 2013) or justin-time solutions (Ekeskär and Rudberg, 2016; Sundquist, et al., 2017; Transport for London, 2013). Lately, the construction industry has started to look at how urban goods transport in general is managed (cf. Langley, 2016; Lundesjo, 2011; Sundquist, et al., 2017). One popular suggestion for reducing the impact of urban goods transports has been to employ urban consolidation centres (UCC's) (Allen, et al., 2014; Björklund, et al., 2017; Browne, et al., 2005). By consolidating goods from multiple suppliers into one shipment, the amount of goods movements within cities can be reduced (Browne, et al., 2005; Gammelgaard, 2012; van Rooijen and Quak, 2010). The idea of consolidating goods to reduce the number of goods movements has now received attention in the construction industry as well, paving the way for construction logistics centres (CLC's) (Lundesjo, 2010, 2011; Transport for London, 2013; Brunge, 2013).

The aim of the CLC is to coordinate deliveries to multiple construction sites within an urban area (Lundesjo, 2010, 2011; Transport for London, 2013; Brunge, 2013). Instead of the traditional situation where many deliveries come to construction sites without any coordination, the use of a CLC can reduce the number of deliveries to site, thus reducing the number of times on-site personnel has to receive and handle materials (Lundesjo, 2010, 2011; Transport for London, 2013; Brunge, 2013).

Figure 5 shows a schematic overview of the functionality of a CLC. The most common procedure is that contractors place orders with their suppliers and these orders are fulfilled either as a direct delivery to site or delivered to the CLC (Brunge, 2013; Lundesjo, 2010, 2011). At the same time, the contractor places a delivery booking in a joint planning system run by the CLC operator for the materials delivery (Lundesjo, 2010, 2011). Materials arrive 
from different suppliers to the CLC, where the materials are received, controlled, registered and put away for storage (Lundesjo, 2010, 2011; Transport for London, 2013). When the materials are needed on the construction site, the contractor call off materials that are picked, packed and delivered (Lundesjo, 2010, 2011; Transport for London, 2013). Often, CLC's also offer value-adding services that can be performed before delivery to site (Lundesjo, 2010). An example can for instance be room, apartment, or house kitting, where materials are combined into a full bill-of-materials for the installation spot (Lundesjo, 2010). Materials are then consolidated into a milk-round delivery where the CLC operator services multiple construction sites within the development area (Brunge, 2013; Lundesjo, 2010, 2011).



Figure 5 - The functionality of construction logistics centres

In theory, utilizing a CLC can alleviate some of the issues faced in the urban transport system such as reducing congestion, emissions, noise and accessibility issues, but utilizing the CLC can also reduce some on-site issues such as having too much materials on site (Transport for London, 2013; Ekeskär and Rudberg, 2016; Lindén and Josephson, 2013). By coordinating the construction sites' materials bookings through joint IT platforms, contractors can plan material flows in accordance with demand (Brunge, 2013; Lundesjo, 2010, 2011). This also allows the operator of the CLC to manage material and resource flows to and from multiple sites in the development area, thus allowing them to act as systems coordinators within the development area (cf. Ekeskär and Rudberg, 2016; Segerstedt and Olofsson, 2010). By having the CLC as a coordinating contact point, main contractors can focus on their operations rather than on establishing contacts and coordinating deliveries with multiple other contractors within the same construction area (cf. Sundquist, et al., 2017; Lindén and Josephson, 2013).

CLC's are often located in close proximity to the construction area, but they can also be in the form of a warehouse solution further from the construction area (Lundesjo, 2011; Transport for London, 2013). In these instances, CLC's are normally combined with a checkpoint at the construction site (Lundesjo, 2011; Transport for London, 2013). A checkpoint can be used as a standalone CLS as well. Figure 6 gives a schematic overview of how a checkpoint works. As is the case with the CLC, the delivery process in the 
checkpoint case starts when the contractor places an order with a supplier. At the same time, the contractor makes a delivery booking in the checkpoints ICT tool (Sundquist, et al., 2017; Ekeskär and Rudberg, 2016). In this type of system, time-slots for deliveries are booked and specified with information on sort of materials, type of vehicle, goods volumes and if any specific handling equipment is needed (Sundquist, et al., 2017). Once the supplier has the shipment ready, a delivery announcement is sent from the supplier to the contractor and the checkpoint operator and the shipment is delivered to the physical checkpoint (Ekeskär and Rudberg, 2016). Here the delivery may have to wait for its allotted time-slot before the final delivery to the construction site is carried out (Ekeskär and Rudberg, 2016).

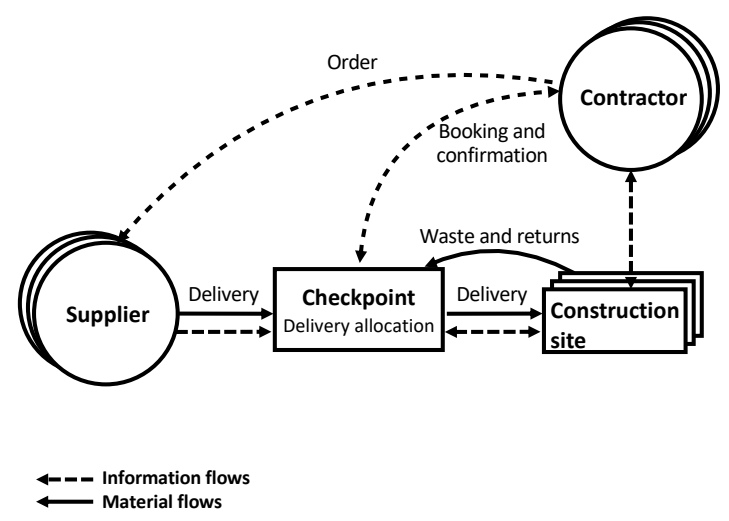

Figure 6 - The functionality of the checkpoint

The main difference between CLCs and checkpoints when it comes to material deliveries is in how the deliveries are planned and carried out. The focus of a CLC is largely on the consolidation of deliveries, whereas the checkpoint takes it point-of-departure in JIT deliveries (cf. Brunge, 2013; Ekeskär and Rudberg, 2016; Lundesjo, 2011; Sundquist, et al., 2017; Transport for London, 2013). Both types of CLS's can also add additional services to their respective service offerings by providing contractors with e.g. supplying and maintaining loading and unloading zones (Transport for London, 2013), warehousing on-site or off-site (Lundesjo, 2010, 2011), logistics-based site plans (Josephson and Saukkoriipi, 2007; Transport for London, 2013), materials handling on-site and off-site (Ekeskär and Rudberg, 2016; Lindén and Josephson, 2013), joint planning systems (Thunberg and Persson, 2014; Thunberg and Fredriksson, 2018), and site coordination (Ekeskär and Rudberg, 2016; Segerstedt and Olofsson, 2010; Josephson and Saukkoriipi, 2007; Sundquist, et al., 2017; Transport for London, 2013).

Of interest is also who initiates, designs and operationalizes the CLS. Different stakeholders can be initiators; e.g. the developer (Ekeskär and Rudberg, 2016) or the municipality (Transport for London, 2013). In some cases, main contractors have also been the ones to decide upon and initiate the use of CLS's in order to coordinate their logistics processes to multiple projects (Danielson, 2007) or to streamline the on-site logistics process (Ek, 2008). 


\subsubsection{Third-party logistics}

Third-party logistics (TPL) can essentially be said to be the outsourcing of a company's logistics function to an external logistics service provider, a "third party", that acts as an intermediary between two supply chain companies (Marasco, 2008; Hertz and Alfredsson, 2003), at least managing and executing transportation and warehousing (Berglund, et al., 1999). Selviaridis and Spring (2007) adds some nuance, saying that TPL is usually associated with offerings that encompasses more services than just transport or warehousing functions. These characteristics, outsourcing logistics functions and offerings of additional services, is something that many contemporary scholars highlight in their works (cf. Maloni and Carter, 2006; Marasco, 2008; Selviaridis and Spring, 2007; Stefansson, 2006; Berglund, et al., 1999). Adding to this, the service offerings must include multiple, bundled services and the relationship between service client and TPL provider should be contractually stipulated over a longer time period for the arrangement to be considered a TPL arrangement (Selviaridis and Spring, 2007; Lai, et al., 2004; SkjoettLarsen, et al., 2006). The reason for using a TPL provider will inevitably affect the relationship between the service client and the provider. Cost reasoning have a tendency to lead to more arm's length relationships whereas knowledge-seeking reasons normally leads to closer relationships (Bolumole, 2001). Through these relationships, the service client and the TPL provider can reach a level of trust that differs from the more adversarial arm's length agreements of sourcing transportation and warehousing on the spot-market (Berglund, et al., 1999). Based on the description above, TPL can be defined as;

"Third-party logistics offers multiple, bundled, value-adding services to customer companies over a contractually established time-period." (cf. Maloni and Carter, 2006; Marasco, 2008; Selviaridis and Spring, 2007)

The bundled services mentioned can be comprised of services such as transport, warehousing, inventory management, value-adding activities such as kitting and assembly work, information activities such as tracking and tracing materials, as well as supplying ICT tools for planning, and reverse logistics (Hertz and Alfredsson, 2003; van Laarhoven, et al., 2000; Shaharudin, et al., 2014). Another important aspect of TPL is the adaptability and level of customization that the TPL service can offer (Stefansson, 2006; Hertz and Alfredsson, 2003). Developing niche offerings (e.g. industry segments or products managed) can be used as a way to increase customer adaptations for TPL (Hertz and Alfredsson, 2003). This is also a way for the TPL provider to widen their overall knowledge, as well as developing the specific knowledge needed for a certain customer or niche (Hertz and Alfredsson, 2003). The challenge for the TPL service provider thus becomes one of balance; how should the service offerings be adapted so as to provide a high level of customization to individual customers and still retain flexibility enough to provide services to multiple customer segments (Stefansson, 2006; Hertz and Alfredsson, 2003)?

One such niche market that has arisen lately is that of construction logistics. Regardless of the CLS chosen, the solutions are often run by TPL service providers (Ekeskär and Rudberg, 2016; Lindén and Josephson, 2013; Lundesjo, 2011; Sundquist, et al., 2017). 
Partly this is due to a lack of logistics know-how from contractors (Ekeskär and Rudberg, 2016), and partly due to TPL providers having a more neutral role to play when it comes to planning, coordinating, executing and controlling the fragmented operations in construction (Segerstedt and Olofsson, 2010; Ekeskär and Rudberg, 2016). The TPL provider can thus act as a systems coordinator for the material and resource flows (Segerstedt and Olofsson, 2010; Ekeskär and Rudberg, 2016) within (e.g.) an urban development project.

\subsubsection{Logistics costs}

Construction is a very cost oriented industry, where an ever-present goal is to reduce costs and increase profits (Shakantu, et al., 2003). The cost side has often been targeted through the sub-contractor and supplier selection processes, where the lowest bid has outweighed performance and management skills (Shakantu, et al., 2003; cf. Dubois and Gadde, 2002; Kristiansen, et al., 2005). With the material intensity of the construction industry, material costs amount to approximately 65 per cent of total construction costs (Fang and Ng, 2011). Reducing the cost of materials through selecting a cheaper supplier thus seems to make some sense. Over the past decades however, the interest for lowering costs by focusing on logistics has increased (cf. Polat, et al., 2006; Said and El-Rayes, 2011). Grawe (2009) highlight that cost efficiency is a "necessity" in logistics and that many practitioners rate cost control and cost reduction as their main priority. The same point is also put forth by e.g. Varila, et al. (2007), Ellram (1995), and Everaert, et al. (2008).

Delivering materials to urban construction sites is of course costly. Vidalakis, et al. (2011) highlight that transport costs can amount to as much as 50 per cent of the materials purchase price, and that these costs can vary over time with fluctuating materials demand (Vidalakis, et al., 2011; Vidalakis, et al., 2013). Logistics activities are often seen as "unnecessary" costs, making them even more of a target for cost reduction efforts (Fang and $\mathrm{Ng}, 2011$; Polat, et al., 2006; Shakantu, et al., 2003; Sobotka, 2000). However, logistics costs are to some extent also intangible, as construction materials often are quoted "as delivered" (Ying, et al., 2014, p. 274). Without understanding logistics costs there is a risk for suboptimising the logistics process. In the long run this can even lead to increased overall logistics costs. Storage costs for instance, can increase if more materials than needed is purchased due to targeting i.e. purchasing costs (Shakantu, et al., 2003). The reasoning behind this cost focus in logistics is twofold; firstly, if costs are reduced and managed, the cost savings can be re-invested in better equipment or materials (Fang and Ng, 2011). Secondly, cost savings can help in increasing a company's return on investment and thus increase shareholder value (Christopher, 2011).

In traditional supply chains, logistics costs are normally seen as indirect costs (Harrison and van Hoek, 2011; LaLonde and Pohlen, 1996). This means that logistics costs are seen as costs incurred through joint usage for different outputs, making the costs difficult to allocate to a specific cost centre. Traditionally, logistics costs are thus allocated to products based on the logistics function that the product utilizes (Harrison and van Hoek, 2011; LaLonde and Pohlen, 1996). These logistics functions also gave way for the initial logistics function-based cost centres such as transport, warehousing, inventory carrying, and 
administration costs (Heskett, et al., 1973). Over time, they have evolved to also include order processing, information and ICT systems, and transport packaging (Stock and Lambert, 2001; Engblom, et al., 2012). Depending on the context of the logistics systems studied, other cost components can also be of importance when evaluating the logistics costs. Some examples can for instance be risk and damage costs, as well as customs and material handling systems (cf. Zeng and Rossetti, 2003; Shakantu, et al., 2003).

On a more general level, logistics costs can be classified into one or more of the following cost centres; transport, warehousing, inventory carrying costs, administration, indirect costs, and procurement (cf. Zeng and Rossetti, 2003; Shakantu, et al., 2003; Engblom, et al., 2012; Stock and Lambert, 2001; Lin, et al., 2001). In reality, what constitutes logistics costs is dependent on the logistics system being studied and the relevant cost components needs to be identified within this context (Fang and Ng, 2011; Harrison and van Hoek, 2011; Shapiro, 1992).

When analysing logistics costs, one must keep in mind that all logistics cost elements are made up of fixed and variable costs. This means that there will be a fixed cost for the physical infrastructure and resources used, but also a variable cost for e.g. time and salary costs. Site storage for instance, can be comprised of receiving and unloading materials, moving them to on-site storage, registering the location of the materials, the cost of storage, etc. (cf. Everaert, et al., 2008; Fang and Ng, 2011). It is thus of great importance to keep track of the actual logistics setup and to map out the cost centres and activities in order to find the most important logistics costs. The key to finding out the composition of the different cost elements lies in identifying the cost drivers for each activity in the logistics process (Vasiliauskas and Jakubauskas, 2007; LaLonde and Pohlen, 1996; Lin, et al., 2001). These are the factors that cause cost changes in the process (Vasiliauskas and Jakubauskas, 2007; LaLonde and Pohlen, 1996; Lin, et al., 2001).

\subsection{Inter-organizational relationships and governance}

As discussed previously, the construction industry is dependent on multiple relationships in order to produce the buildings and infrastructure we use daily. We may hope that social norms and exchanges can allow for these relationships to form a sort of self-governing system (cf. Emerson, 1962; Homans, 1958), but reality can often be quite different and regulatory agreements may be needed. The process of setting up these regulations is dependent on the ruling governance strategy. Hufty (2011, p. 405) define governance as "the processes of interaction and decision-making among the actors involved in a collective problem that lead to creation, reinforcement or reproduction of social norms and institutions". Boissinot and Paché (2011) highlight that governance can be used as a means to monitor, select, incentivize or socialize a relationship amongst stakeholders with a general purpose of aligning interests and reduce information asymmetry. Governance strategy can thus be seen as the strategy for how social and economic coordination should take place within a specific area (Williamson, 1999; Jereb, 2017). 
Klakegg (2009) point out that governance includes "developing visions and strategy, establishing frameworks for business, making decision and giving priority, empowering and maintaining follow-up of management, and confirming compliance with requirements (Klakegg, 2009, p. 4). This can be translated into three levels of governance; strategic, tactical and operational governance (Boissinot and Paché, 2011). The strategic level sets the long-term goals and guidelines of the governance solution, the tactical deals with how the long-term goals can be achieved through regulations and incentives, and the operational governance sets the rules for the daily activities (Schmidt and Wilhelm, 2000; Boissinot and Paché, 2011).

It is also important to note that different stakeholders have different drivers and needs from a governance strategy; private actors are driven by financial consideration whereas public authorities and companies are driven by providing public values (Caldwell, et al., 2009; Teisman and Klijn, 2004). Friction and challenges between the public and the private will occur (Norrman and Henkow, 2014) so the different perspectives need to be consolidated into a joint, or at least accepted, vision for the governance strategy to be successful (Klakegg, 2009). Finding the right governance enablers is thus important in facilitating decision making and operations when setting up a governance strategy (cf. Jereb, 2017; Norrman and Henkow, 2014).

\subsubsection{Control mechanisms and governance enablers}

Regardless of how the utilized governance strategy is set up, some control mechanisms must be in place to ensure that stakeholders adhere to the set regulations and do not act opportunistically (Caldwell, et al., 2009). Depending on the relationship between the different stakeholders, both formal and informal control mechanisms can be suitable (Boissinot and Paché, 2011; Caldwell, et al., 2009). Formal control is often applied as contractually stipulated regulations (Caldwell, et al., 2009; Williamson, 2008). This often leads to an adversarial relationship between the governing, and the governed, entities in the relationship (Boissinot and Paché, 2011; Winch, 2001) with a lower level of trust between them (Boissinot and Paché, 2011; Vivek, et al., 2009). Contracts are often used as a control mechanism early on in a relationship, but is not always the best alternative. Norrman and Henkow (2014, p. 755) for instance, highlight that traditional contracts and regulations may not cater to a more innovative relationship where responsibilities are divided in new ways. In these cases, it may be that control mechanisms needs to be more informal and based on "soft" values such as trust, commitment, and information exchange (Caldwell, et al., 2009; Williamson, 2008). These are, however, not to be seen as an "easy way out" but are often time-consuming and resource demanding in order to work properly (Caldwell, et al., 2009; Williamson, 2008). Choosing control mechanisms are important, and the urge to "hedging one's bets" on multiple control mechanisms can often arise. It must however be recognized that multiplication of control mechanisms does not necessarily give added value in terms of more control and saved costs (Boissinot and Paché, 2011). 


\section{Research design and method}

This chapter describes the overall research design and motivates the choice of research methods. It also describes how the research in each paper was conducted.

\subsection{Research design}

To fulfil the purpose of this thesis, two research questions were put forth in chapter 1 . Introduction. The first RQ deals with the coordination of different stakeholders and how they are affected when a CLS is utilized. The second RQ explores how material flows and costs in urban construction projects are affected by a CLS. As such, it goes into a more technically detailed level than the previous one. The two research questions also reflect the research design of this thesis project; the first part of the project aimed at investigating stakeholder experiences of inter-organizational relationships and construction logistics solutions. This was followed by more technically oriented studies where material flows, and costs were in focus. Figure 7 shows how the research design and RQ's relate to the research scope of the thesis.

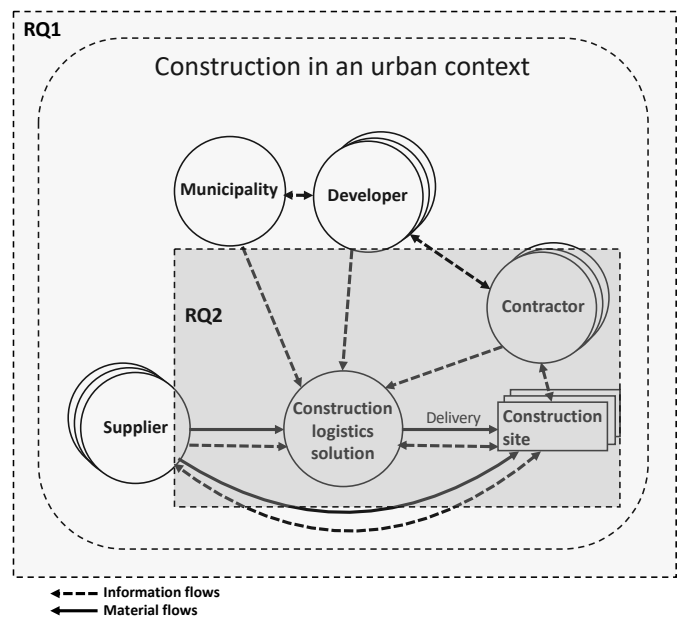

Figure 7 - Relation between research design, research questions, and research scope

\subsection{Research process}

The research process of this thesis project consists of four studies that were conducted over the course of approximately three years within two research projects; the Development 
Fund of the Swedish Construction Industry (SBUF) financed Total cost analysis of logistics solutions in the construction supply chain (TCA) and the JPI Urban Europe/Sweden's Innovation Agency (VINNOVA) funded project Construction In Vicinities: Innovative Cocreation (CIVIC). The TCA project aims at analysing the impact that the use of innovative logistics services has on productivity, efficiency and overall costs of the construction process, whereas the aim of the CIVIC project is to facilitate and support transports to and from construction sites in a way that minimizes disruptions to the surrounding society.

The four studies are presented as papers (see Figure 8) and each of these help in answering the research questions of this thesis. One of the papers is a literature review, conducted with a systematic approach. Papers 2 and 3 are exploratory single case studies with descriptive elements, and paper 4 is a descriptive embedded single case study. Figure 8 depicts the overall research process.

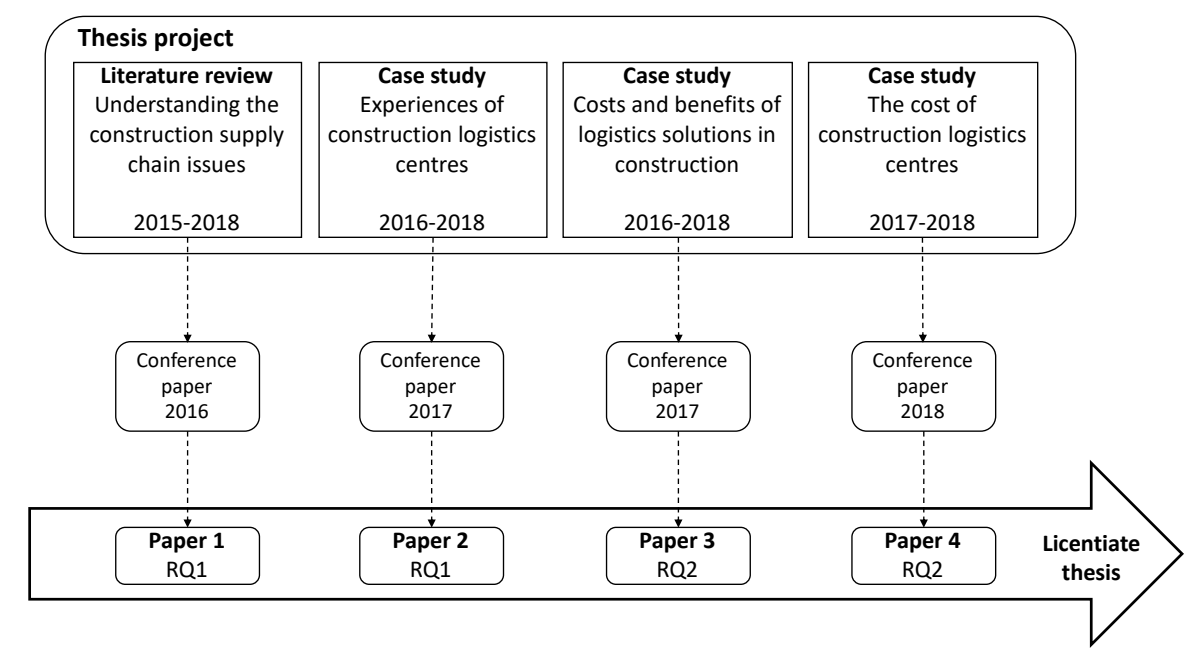

Figure 8 - The research process

The research process is based on gathering initial knowledge before collecting empirical data, i.e. a deductive approach. In the first phase, a comprehensive literature review (paper 1) was conducted, and the author gained insight into the mechanisms and interorganizational relationships of the construction industry. However, during this phase, the author also had to revisit literature in an inductive manner to allow for a deepening of the synthesis and analysis, resulting in a deductive-inductive approach in paper 1.

This approach was carried over to the empirical studies, where literature reviews were conducted as preparation for the empirical data collection as well as to provide analytical frameworks for the studies (paper 2, 3, and 4). Papers 2 and 3 have also been developed from their prior conference versions through deepening of the literature reviews, as well as through additional empirical data collection. 


\subsection{Choice of method}

Theory building research is important in that it can add new insights as to how real-world problems can be tackled (Wacker, 1998; Meredith, 2001). Furthermore, theory building research can lead to these new insights being analysed and tested in a real-world context from where the insights were derived, or in a similar context to test the new theory (Wacker, 1998; Meredith, 2001). To cement the theory building effort, the novel theories must of course be tested and validated in other real-world contexts (Wacker, 1998; Meredith, 2001). According to Wacker (1998) and Meredith (1993; 2001), theory building is an iterative process that follows the general steps of description, explanation, and testing.

This research project is primarily explorative, investigating how CLS's can be used as a means to coordinate and govern construction material flows in urban areas. As such, it can be said to be, to some extent, theory building (Voss, et al., 2002; Meredith, 2001), albeit not necessarily theory testing, an aspect that (Meredith, 1993) highlight as equally important in developing new theories.

Theory building research can be divided into two main categories, i.e. analytical research and empirical research (Wacker, 1998). This thesis consists of both types; paper 1 is a literature review with a systematic approach, and as such it falls into the realm of analytical research (Wacker, 1998). Papers 2 and 3 are explorative case studies with descriptive elements, whereas paper 4 is a descriptive case study. All three are thus empirically based (Wacker, 1998). More on how the studies were carried out can be found in sections 3.3.3 3.3.6 below.

\subsubsection{Analytical research through literature reviews and conceptual modelling}

As described by Wacker (1998), theories can be built from analytical research, which can be further divided into conceptual, mathematical, or statistical analysis (Wacker, 1998, p. 378). This section is dedicated to analytical research through conceptual analysis and the role literature reviews play in this process.

The purpose of analytical conceptual research is to add new insights into traditional problems (Wacker, 1998). From this, interpretations can be derived to add insights and develop theories (Wacker, 1998; Meredith, 1993). This is done through the logical development of relationships between different concepts into a comprehensive theory (Wacker, 1998). Meredith (1993) adds to this by further differentiating how conceptual research can be performed, namely through conceptual modelling or development of conceptual frameworks. A conceptual model can be defined as a set of concepts used to describe an event, object, or process, whereas conceptual frameworks can be defined as a collection of two or more interrelated propositions that try to explain and provide understanding of an event, object, or process (Meredith, 1993).

A literature review is conducted in order to obtain knowledge about research gaps, analyse current state of knowledge in a particular field, and to synthesize the findings to produce new knowledge (Jesson, et al., 2011). In that sense, literature reviews fall under the categorization of analytical conceptual research (Jesson, et al., 2011; Wacker, 1998; 
Meredith, 1993). A literature review can range from a traditional scoping review to a systematic review with various degrees of systemic influences throughout (see Figure 9).

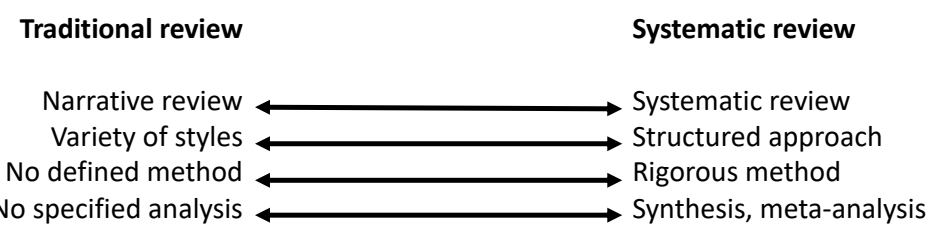

Figure 9 - A continuum of literature review research approaches (Jesson, et al., 2011, p. 11)

This research project contains conceptual analysis through traditional literature reviews (papers 2, 3, and 4), conceptual modelling through synthesizing literature and empirical data (paper 4), and a systematic literature review (paper 1).

\subsubsection{Empirical research through case studies}

As mentioned above, Wacker (1998) divides theory building research into two categories; i.e. analytical and empirical research. This section is dedicated to empirical research through case studies.

Case study research has become a well-established research methodology for obtaining empirical results within qualitative research (Yin, 2014). The upwards trend of using this methodology however, is not necessarily an indication of how good case studies are performed or if they conform to the general case study methodology.

A common critique against case study research in general and single case study research in particular is that it is difficult to generalize and build theory from case research, owing to the specific nature of a case (Eisenhardt, 1989; Flyvbjerg, 2006). Depending on how the case is chosen, either randomly or information-oriented, the possible generalizability may be affected. By taking an information-oriented stance in case selection, a researcher may be able to increase the possibility of obtaining as much valuable information as possible (Flyvbjerg, 2006). It is true that generalization based on a single case study can be difficult to achieve as it only gives a snapshot of one specific case (cf. Eisenhardt, 1989; Flyvbjerg, 2006). It does however, enable in-depth understanding of the phenomenon's underlying mechanisms (Yin, 2014). As such, case study methodology is a valid choice for theory building research.

Eisenhardt (1989) also discusses the theory building qualities and abilities of case study research and derives at a conceptual framework for theory building through case study research. The framework consists of eight steps with an emphasis on the preparation of the research team and getting access to case study objects (Eisenhardt, 1989, p. 533). Flyvbjerg (2006) challenges the non-applicability of case studies in theory building, and argues that case study research can be used to build deep, context-dependent knowledge in a way that "heavy" theories and quantitative knowledge cannot (Flyvbjerg, 2006). He goes on to argue that case study research can develop scientific knowledge through generalization of single case studies as well as generate and test hypotheses (Flyvbjerg, 2006). Further he argues 
that case study as a research methodology does not contain a greater verification bias than other scientific methods and that it is not difficult to summarize due to case study as a method, but rather due to the context and properties of the case studied. (Flyvbjerg, 2006)

The empirically based part of this research project is grounded in case studies; two explorative single case studies at two different development projects, and one descriptive embedded single case study at one of the previously mentioned development projects. The two explorative single case studies allowed for depth in the in-case analysis whereas the embedded single case study also gave the opportunity to analyse different units within the same main case.

\subsubsection{Paper 1 - Understanding logistics issues in the construction supply chain}

The overall purpose of paper 1 is to unravel issues related to logistics and relationships in the construction supply chain and to give further insights into why the full potential of logistics and supply chain management are not yet reached. As such, the focus of this individual study is on the wider aggregation level (see Figure 10), taking in a holistic view of the construction context.

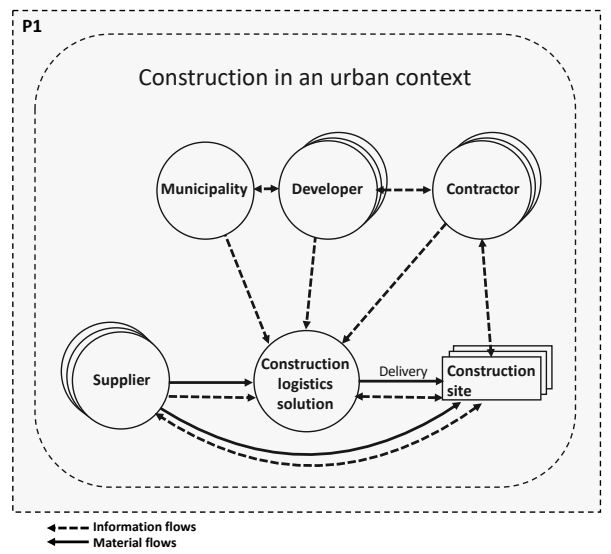

Figure 10 - Focus of paper 1

The purpose of the study is fulfilled through a literature review. The review has been conducted through a systematic approach and by performing content evaluation and synthesis of the findings (Seuring and Gold, 2012; Seuring and Müller, 2008).

In order to provide as much rigor as possible, the methodology used in the review process was adapted from the frameworks of Seuring and Müller (2008), and Evangelista and Durst (2015). The methodology followed the following four steps;

(1) Material collection: A search strategy was designed, and material was retrieved in accordance with the strategy's inclusion and exclusion criteria (Evangelista and Durst, 2015). Literature searches were conducted in the Emerald Insight (www.emeraldinsight.com) and SCOPUS (www.scopus.com) databases using combinations of the keywords construction, supply chain management, logistics, 
and third-party logistics in titles, abstracts and keywords. The inclusion and exclusion criteria were set to include only published, peer-reviewed scientific journal articles. The searches were conducted in November and December 2015, allowing for articles published early in 2016 to be included. No other delimitations were set regarding time-period of publication. The unit of analysis was defined as the individual article and a collection of articles formed the output (Seuring and Müller, 2008; Evangelista and Durst, 2015).

In total, the described searches yielded 3230 published journal articles. Each abstract was read to assess whether the article was within scope of the study. Based on the abstracts, 494 of the articles were selected for further evaluation and coding. An additional read-through of abstracts, introduction and conclusions yielded a final selection of 142 articles.

(2) Category selection: To allow for a deeper analysis of the selected articles, further classification of the material was needed (Seuring and Müller, 2008; Evangelista and Durst, 2015). Initially, theory-based classifications were made as this helps in ensuring the validity of the review (Seuring and Gold, 2012). This also allows for having a baseline structure for the themes within the review. As the review progressed, the categories were revised to better suit the studied material.

The final categorizations are shown in Table 1. These analytic categories were applied as a means to structure the material and answer the research questions.

Table 1 - Categorization of articles in paper 1

\begin{tabular}{l|l}
\hline Main category & Subcategories \\
\hline Supply chain management & $\begin{array}{l}\text { SCM principles, modularization and industrial house- } \\
\text { building, information and communications technology, } \\
\text { relationship management }\end{array}$ \\
\hline Logistics & $\begin{array}{l}\text { Logistics management, information and communication } \\
\text { technology, performance, procurement, reverse logistics }\end{array}$ \\
\hline Third-party logistics & Performance, project management \\
\hline
\end{tabular}

(3) Descriptive analysis: The collected material was analysed from formal aspects such as distribution of articles over time, methodology, and categories within the three fields of SCM, logistics and TPL in construction (Seuring and Müller, 2008; Evangelista and Durst, 2015). This step was essential in highlighting how the interest for SCM, logistics and TPL in construction has grown.

(4) Material analysis: The material was analysed in an inductive manner within the topical categories identified in step 2 (Seuring and Müller, 2008; Evangelista and Durst, 2015). The articles were read thoroughly, important passages were underlined, and notes were taken with the purpose of extracting the important findings from each of the articles in the sample. Short summaries of the articles were written, providing input to the material analysis. 
While assembling the results of the review, the findings from the different categories were grouped together and a descriptive representation of SCM, logistics, and TPL in construction took form. This type of synthesis can be likened to synthesis by interpretation described by Rousseau, et al. (2008, p. 496), where the goal of the synthesis is to translate key interpretations from one study to another. As such it was deemed as the most appropriate form of synthesis for this literature review. This step was crucial to fulfil the purpose of paper 1.

An early version of paper 1 was presented at the $3^{\text {rd }}$ VREF Conference on Urban Freight in 2016. The paper is currently under revision as a working paper, to be submitted to journal.

\subsubsection{Paper $\mathbf{2}$ - Experiences of construction logistics centres in urban development}

The purpose of paper 2 is to develop guidelines for how to set governance strategies for construction logistics centres in urban development projects. When implementing a CLS, different stakeholders will be affected. As such it is vital to investigate the different stakeholder perspectives affected. The focus of paper 2 is thus on the main stakeholders identified and the CLC. The paper also takes the urban context into consideration (Figure 11).



Figure 11 - Focus of paper 2

To be able to provide guidelines for how to set up the governance strategies connected to a construction logistics centre, the authors opted for an exploratory single case research design with descriptive elements (Yin, 2014).

Four different perspectives of the CLC within Stockholm Royal Seaport (SRS) have been studied, i.e. the municipality in the form of the city of Stockholm, the TPL provider operating the CLC, three main contractors building within the SRS area, thus utilizing the CLC services, and two developers. The city of Stockholm is responsible for the development project and has a development office in the SRS area. The TPL provider is an experienced TPL provider from mechanical industry that entered into the world of construction logistics with the CLC in the SRS area. The main contractors are building between one and three apartment buildings within the SRS area, with time frames for the 
projects of between 23 and 33 months. Developer 1 is a municipal housing company and frequently source their contractors on turn-key contracts. Developer 2 is a private housing company that produce all their projects with in-house personnel. Figure 12 shows the logistics process studied in paper 2 .

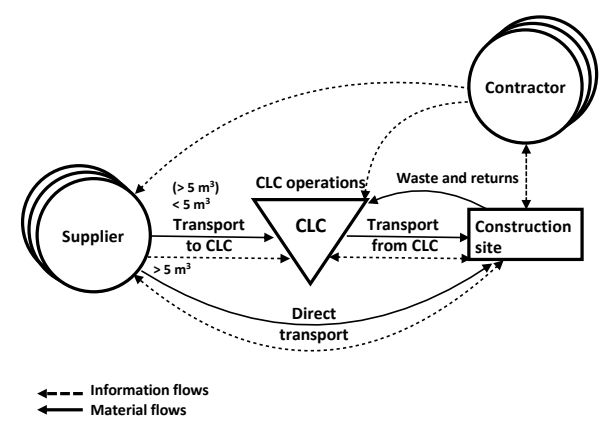

Figure 12 - The logistics processes studied in paper 2

The case study was conducted through an iterative process based on Yin (2014). The case study was firstly prepared through a comprehensive literature review. As preparation, interview guides and case study protocols were developed. These were revisited continuously to improve the data collection process. Data was collected during 2016 and 2017 through, in total, eleven semi-structured interviews, seven on-site observations, and taking part of multiple project documents and site layout plans. The authors have also participated in the education given by the TPL provider to all those who work within the SRS area.

A literature review of CLC's and governance strategies was conducted and summarized into an analytical framework. This framework was thereafter used to structure the analysis. The collected experiences of the different stakeholders were compared to the analytical framework to provide the guidelines for how to set governance mechanisms and fulfil the purpose of the study.

An earlier version of paper 2 has been presented as a conference paper at the $29^{\text {th }}$ annual NOFOMA Conference in 2017. The paper is currently submitted for review in Construction Innovation.

\subsubsection{Paper 3 - Finding cost effects and benefits of construction logistics solutions}

Employing CLS's often leads to logistics costs becoming visible through the invoices sent by the operator, whereas the benefits are hard to quantify. Thus, the use of CLS's is still met with a level of scepticism. The purpose of paper 3 is to investigate what possible benefits, alongside with the effect on costs, can be realized when employing a CLS. As such, the focus of paper 3 is on the CLS, taking in the perspectives of the operator and the contractors of a large construction project that has implemented and used a TPL solution (see Figure 13). 




Figure 13 - Focus of paper 3

The case study in paper 3 investigates the logistics operations of a large office building project where a construction management (CM) company has developed and implemented a CLS. The logistics solution studied consists of three main areas; a consolidation terminal where materials are re-routed if the deliveries are not made with sufficient fill rates, an onsite materials handling team that receives and distributes materials at the construction site, and a standardized planning system and process. Figure 14 illustrates the logistics solution studied in paper 3 .



Figure 14 - The logistics solution studied in paper 3

To allow for a focused and in-depth approach, the research design builds upon four activities (Yin, 2014); preparation, data collection, analysis, and dissemination. The research design is iterative, indicating that each step has been revisited over the course of the research project. This allowed the authors to get the best possible insight and result from the study. The study was planned for in collaboration with the CM company. This ensured that the research team had access to the right people and data sources. The case study was prepared through a literature review regarding SCM, logistics and the use of TPL in construction. Data collection was prepared and revisited throughout the research process. 
Before each interview or site visit, the researchers prepared by discussing the purpose and goal of the exercise.

Data was collected through eight semi-structured interviews with logistics representatives from the CM company, two on-site visits at the construction site, and one visit to the logistics terminal. The authors also reviewed project documents and the CM company's project planning tool. The final phase of the research process is based on analytical and conceptual reasoning (Wacker, 1998), grounded in the results from the literature review and the case study.

Paper 3 has previously been presented as a conference paper at the $24^{\text {th }}$ annual EurOMA Conference in 2017. The paper is currently under revision as a working paper, to be submitted to journal.

\subsubsection{Paper 4 - Determining the cost of construction logistics centres}

The purpose of paper 4 is to propose a model for calculating the costs of a CLC by analysing what activities and costs a CLC entails. The focus of the paper is on the activities in, and surrounding, the CLC with regards to material deliveries to site (see Figure 15).



Figure 15 - Focus of paper 4

The case in paper 4 is a development of the case studied in paper 2. The main difference is in the case boundaries set in the two papers; in paper 4, the case is delimited to only include the delivery processes to construction sites in SRS and has been divided into four subprocesses; direct delivery to site, delivery to CLC, operations within the CLC, and transport from the CLC to site (see Figure 16). Apart from the CLC itself, three projects in SRS that utilizes the CLC have been studied. By embedding and analysing three individual cases within the main case, the authors add to the generalizability of the main case (Yin, 2014). 


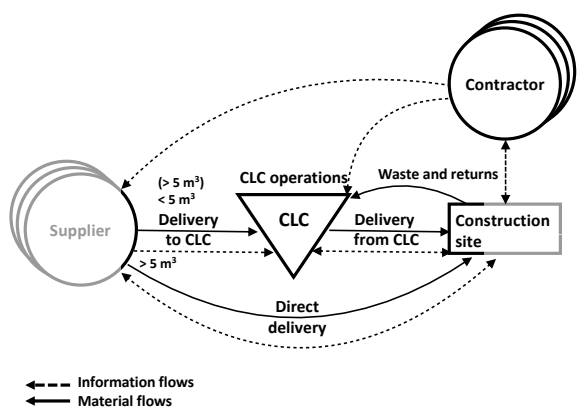

Figure 16 - The delivery processes studied in paper 4

To fulfil the purpose, an activity-based costing (ABC) approach has been utilized in setting the relevant costs. $\mathrm{ABC}$ is a cost accounting technique that highlights relationships between activities and resource consumption (Cooper and Kaplan, 1991; Gríful-Miquela, 2001). The ABC modelling is based on the material and information flows of the SRS CLC as presented in Figure 16. This representation is based on the information obtained through interviews and project documentation that form the base of the case study. As the purpose of paper 4 is to find a feasible way to cost model the CLC, activities at the suppliers and on the construction sites, are delimited from the $\mathrm{ABC}$ modelling and subsequent analysis.

The $\mathrm{ABC}$ analysis follows the seven-step process outlined below (based on LaLonde and Pohlen, 1996; Lin, et al., 2001; Gríful-Miquela, 2001);

(1) Determine the process of interest and set system boundaries: The process chosen in paper 4 is the delivery process of the SRS CLC. This was further divided into the four sub-processes identified and described above; direct delivery to site, delivery to CLC, operations within the CLC, and transport from the CLC to site.

(2) Break down the chosen processes into activities: The breakdown of the subprocesses into activities was performed with the aid of the CLC operator and observations during site visits.

(3) Identify the resources consumed in these activities: The identification of resources was performed with the aid of the CLC operator and observations during site visits.

(4) Identify cost drivers for the activities: The cost drivers were identified based on logistics cost drivers found in literature (cf. Everaert, et al., 2008; Fang and Ng, 2011; Gríful-Miquela, 2001; Schniederjans and Garvin, 1997) and the activities and resources identified in the four sub-processes.

(5) Gather cost data: Cost data was collected with the aid of the CLC operator and comprised the invoice data for all projects in the SRS area during the time-period 2013-2016.

(6) Allocate costs to the activities: This was performed in accordance with the activity and resource breakdown performed in steps (2) - (4). 
(7) Analyse the cost information from a total cost perspective: This step summarized the activity costs into five cost equations; one total cost equation comprised of cost equations for each of the four sub-processes. These equations then formed the base for the cost calculations for the three studied construction projects.

Paper 4 is a conference paper, scheduled to be presented at the $30^{\text {th }}$ annual NOFOMA Conference in June 2018.

\subsection{Research quality}

In order to develop relevant, valid, and testable new theories, Eisenhardt (1989) argues that previous literature needs to be combined with new empirical evidence. This does however, imply that in order for the new theory to be sound, some measures of research quality must be in place (Eisenhardt, 1989). Regardless of the type of research conducted, producing results that can be trusted to be valid and reliable is of great importance (Karlsson, 2009; Eisenhardt, 1989). This means that the researcher must be transparent regarding how the research has been conducted and how the researcher has addressed the issues of validity and reliability (Karlsson, 2009; Yin, 2014). The following sections discuss how to ensure research quality for the two chosen research methods, and how this has been tackled in the studies of this thesis.

\subsubsection{Research quality in content analysis-based literature reviews}

Depending on the goal of the literature reviews, different review approaches can be adopted. A traditional review can be said to be a gap analysis whereas a conceptual review aims to synthesize areas of conceptual knowledge to further the understanding of a certain issue (Jesson, et al., 2011, p. 15). The systematic review on the other hand, applies more rigorous methodology to the review, and thus can give greater insight into a problem area (Cronin, et al., 2008; Jesson, et al., 2011). Regardless of the approach chosen, literature reviews should take a critical approach (Jesson, et al., 2011; Cronin, et al., 2008). It should be noted that literature reviews should be conducted by multiple researcher to reduce interpretation bias from a single researcher (Seuring and Gold, 2012; Rousseau, et al., 2008).

Even though traditional and conceptual reviews rarely provide a deep methodology description, it can be helpful for the author to adopt and follow certain methodological approaches, e.g. taking notes on the papers read, looking out for bias in the own writing, find materials that are in opposition or brings forth other viewpoints than that of the author, etc. (Jesson, et al., 2011). This will help in improving validity and reliability of the review (Jesson, et al., 2011). In systematic reviews, it is of great importance to show the methodology used and how it has been followed (Jesson, et al., 2011; Cronin, et al., 2008). A rigorous description of how the collection of literature was made will enhance the validity and reliability of the review (Jesson, et al., 2011; Seuring and Gold, 2012; Rousseau, et al., 2008). Seuring and Gold (2012) proposes four milestones for conducting content analysis-based literature reviews; material collection, descriptive analysis, pattern of analytic categories, and material evaluation and research quality (see Table 2). As paper 
1 in this research is a content analysis-based literature review with a systematic approach, this milestone model will be used to discuss how and if research quality has been ensured.

Table 2 - Milestones for content analysis in literature reviews (Seuring and Gold, 2012, p. 552)

\begin{tabular}{l|l}
\hline Milestones & \multicolumn{1}{c}{ Critical considerations } \\
\hline Material collection & $\begin{array}{l}\text { Defining and delimiting material } \\
\text { Specifying the topic: suitable keywords for database search } \\
\text { Scope of journals: selective or general } \\
\text { Defining unit of analysis } \\
\text { Consistent throughout the analysis } \\
\text { Mind bias from similar papers by same group of authors }\end{array}$ \\
\hline Descriptive analysis & $\begin{array}{l}\text { Distribution over time period } \\
\text { Distribution over publication outlets (particularly journals) }\end{array}$ \\
\hline categories & $\begin{array}{l}\text { Deductive versus inductive category building (corresponds to } \\
\text { theoretically grounded versus explorative research approaches) } \\
\text { Default two-step approach: 1. Deductive category building, 2. } \\
\text { Iterative cycles of inductive category refinement while coding }\end{array}$ \\
\hline Material evaluation & $\begin{array}{l}\text { Need of iterative coding cycles in case of inductive category } \\
\text { refinements or deficient inter-rater reliability } \\
\text { Transparency and objectivity (clear coding rules from outset) } \\
\text { Reliability (particularly inter-rater reliability): at least two coders, } \\
\text { cross-coding for testing agreement or aligning mental schemes } \\
\text { Validity (theoretical foundation, specific inductive refinements) }\end{array}$ \\
\hline
\end{tabular}

In the material collection phase, the following steps were undertaken to provide rigour in the literature review process:

- A search strategy was designed based on keywords pertaining to the research areas of interests; construction, supply chain management, logistics, and third-party logistics. These keywords were discussed with the author's supervisors and deemed to be sufficiently precise, while still allowing for a wide collection of articles.

- Delimitations were set to include only peer reviewed journal articles from two databases (SCOPUS and Emerald Insight).

- Searches within these databases were general and non-discriminatory to allow for articles published in non-traditional construction management journals to be part of the sample. Searches were made in titles, abstracts and keywords to retrieve the most suitable articles.

- No delimitations were set regarding time-period of publication, allowing for a wide selection of articles that would represent the development of the research area in the descriptive analysis.

- The unit of analysis was defined as the individual article.

- Abstracts were read carefully from a content point-of-view to find the articles suitable for the review, and for further classification. 
- All searches and articles were recorded in an electronic database for transparency.

In the descriptive analysis, the analysis itself is less susceptible to issues in validity and reliability as it deals with aspects such as publication time, methodology, and journal of publication. However, paper 1 also highlights what category the different articles have been classified as in the descriptive analysis. In order to provide rigour in the descriptive analysis, the following measures have been taken:

- The collected material was analysed from formal aspects such as distribution of articles over time, journal, and methodology. Articles over time was decided based on year of publication. Methodology was based on the description of methodology in the articles themselves, thus being an objective measure.

- The classification of articles is the part of the descriptive analysis that is most susceptible to interpretation bias. The classification is however based on deductiveinductive theoretical reasoning (see below)

To allow for a deeper analysis of the selected articles, classification of the material is vital. Seuring and Gold (2012) recommends theory-based classifications as this helps in ensuring the validity of the review while also allowing for having a baseline structure for the themes within the review. The following steps were undertaken during the pattern of analytic categories phase to ensure rigour:

- The initial category classifications were theory-based. As the author is the sole author of paper 1, these classifications were discussed with the author's supervisors. This reduced some of the interpretation bias.

In the material evaluation and research quality phase, the following steps were taken.

- As the review progressed, the categories described above were revised to better suit the studied material. This deductive-inductive approach allowed for some flexibility while still being based on a theory-based classification. This iterative process can, according to Seuring and Gold (2012), enhance the validity of the study further as the analysis is based on existing theory while still being adjusted to the specific sample.

- The coding and evaluation was discussed with the authors supervisors and other colleagues in order to reduce interpretation bias. The paper was also presented as a conference paper and was revised after comments from knowledgeable conference participants. This can, to some extent, be likened to "discursive alignment of interpretation" as discussed by Seuring and Gold (2012), as it allowed the author to align his interpretations to those of more senior researchers.

Finally, to reduce any question marks regarding the research quality of paper 1, the author has provided a detailed methodology section in the final paper in order to ensure transparency in the overall research process. 


\subsubsection{Research quality in case study research}

With the criticism against using case studies as a theory building research method due to the specificity of each case, showing the research quality through validity and reliability of the research is especially important (Yin, 2014; Voss, 2009). This can be done through the four case study tactics described by (Yin, 2014) in which these tactics test construct validity, internal validity, external validity, and reliability as shown in Table 3.

Table 3 - Means to ensure research quality (Yin, 2014, p. 45)

\begin{tabular}{|c|c|c|}
\hline Tests & Case study tactic & $\begin{array}{l}\text { Phase of research in } \\
\text { which tactic occurs }\end{array}$ \\
\hline $\begin{array}{l}\text { Construct } \\
\text { validity }\end{array}$ & $\begin{array}{l}\text { Use multiple sources of evidence } \\
\text { Establish chain of evidence } \\
\text { Have key informants review draft case study report }\end{array}$ & $\begin{array}{l}\text { Data collection } \\
\text { Data collection } \\
\text { Composition }\end{array}$ \\
\hline $\begin{array}{l}\text { Internal } \\
\text { validity }\end{array}$ & $\begin{array}{l}\text { Do pattern matching } \\
\text { Do explanation building } \\
\text { Address rival explanations } \\
\text { Use logic models }\end{array}$ & $\begin{array}{l}\text { Data analysis } \\
\text { Data analysis } \\
\text { Data analysis } \\
\text { Data analysis }\end{array}$ \\
\hline $\begin{array}{l}\text { External } \\
\text { validity }\end{array}$ & $\begin{array}{l}\text { Use theory in single case studies } \\
\text { Use replication logic in multiple case studies }\end{array}$ & $\begin{array}{l}\text { Research design } \\
\text { Research design }\end{array}$ \\
\hline Reliability & $\begin{array}{l}\text { Use case study protocol } \\
\text { Develop case study database }\end{array}$ & $\begin{array}{l}\text { Data collection } \\
\text { Data collection }\end{array}$ \\
\hline
\end{tabular}

The concept of construct validity can be defined as identifying the correct operational measures for the studied objects (Yin, 2014; Gibbert, et al., 2008). The following measures have been taken to ensure construct validity in this research:

- For all three case studies (papers 2, 3, and 4), multiple sources have been used for data collection. Interviews, observations, project documentation, audit reports, project management tools, statistics and company websites have been used as data sources.

- All three case studies have followed an iterative process where literature has been reviewed prior to empirical data collection and revisited afterwards, to ensure that enough and correct data was collected as well as to help in the analysis. This iterative process should strengthen the construct validity. The literature has also helped in validating findings from the empirical data. The empirical data on the other hand has revealed the need to deepen the literature review in papers 2 and 3.

- Interview protocols and notes from documentation reviews have been discussed with respondents and project officials in order to validate the understanding of documents and interview responses.

- Draft case study reports have been sent to key informants for review.

Internal validity refers to whether the relationship between cause and effect can be ensured (Yin, 2014; Voss, 2009; Karlsson, 2009; Gibbert, et al., 2008). According to Yin (2014), internal validity is more of a concern when it comes to explanatory case studies. Two of 
the three case studies reported in this research project are exploratory case studies and the third is a descriptive case study, hence the internal validity is of lesser concern. Regardless, the following measures could be argued to strengthen the internal validity of the research:

- All three case studies in this thesis were written by two authors. Throughout all the phases of the studies, the authors have collaborated closely and discussed any unclear aspects of data collection, data collected, statements in literature, or findings.

- Multiple data sources and data collection methods have been used, allowing for triangulation of results.

External validity is defined as how generalizability of the case study results is ensured (Yin, 2014; Voss, 2009; Karlsson, 2009; Gibbert, et al., 2008). The three case studies in this thesis are conducted at a large urban development project in Stockholm, Sweden, and a large construction project in the Swedish municipality Solna. All the companies and municipal representatives participating in these case studies operate in Sweden. This fact does have implications on the generalizability of the results. The following measures have been taken to ensure external validity:

- Extensive literature reviews have been undertaken in all three case studies and some of the findings from the case studies have also been seen in examples in literature. This increases the likelihood of the results being generalizable.

- As research findings are analysed with the aid of an international literature base, the case studies offer some directions for companies and municipalities in contexts similar to the Swedish one.

- By embedding and analysing three individual cases within the main case in paper 4 , the authors add to the generalizability through replication logic.

- Data has been collected through different methods and from different sources, thus allowing for some triangulation to be undertaken.

Reliability is the extent to which a study can be repeated by another researcher and still reach the same conclusion (Yin, 2014; Voss, 2009; Karlsson, 2009). Reliability is a difficult measure as data collection and analysis is carried out by individuals, and some involuntary bias may be present (Yin, 2014; Voss, 2009). However, treating data and applying a structured methodology can increase reliability (Yin, 2014; Voss, 2009; Gibbert, et al., 2008). In this research, reliability has been ensured through the following measures:

- Well-structured interview guides and research protocols have been used in the data collection phases of the three case studies.

- Drafts and notes from interviews and observations have been stored electronically and as hardcopies. This allows for case study material to be reviewed and controlled if necessary. 


\subsection{Authors statement}

The literature review (Janné, 2018), in this thesis referred to as paper 1, was authored solely by the thesis author. However, both supervisors have been supporting the thesis author throughout the research process of paper 1, through feedback and ideas in their respective roles as supervisors. An early version of this paper was presented at the $3^{\text {rd }}$ bi-annual VREF Conference on Urban Freight in 2016. The paper is currently under revision as a working paper.

In paper 2 (Janné and Fredriksson, 2018a), the thesis author collaborated with the authors co-supervisor. Both authors contributed equally to the paper throughout the study. An earlier version of this paper has previously been presented as a conference paper at the $29^{\text {th }}$ annual NOFOMA Conference in 2017. The paper is currently submitted for review in Construction Innovation.

In Janné and Rudberg (2017), in this thesis referred to as paper 3, the author collaborated with his main supervisor. Both authors contributed equally to the paper in all stages of the research process. Paper 3 has previously been presented as a conference paper at the $24^{\text {th }}$ annual EurOMA Conference in 2017. The paper is currently under revision as a working paper.

In Janné and Fredriksson (2018b), referred to as paper 4 in this thesis, the author collaborated with his co-supervisor. Both authors contributed equally to the resulting paper. This paper is to be presented at the $30^{\text {th }}$ annual NOFOMA Conference in June 2018. 


\section{Summary of papers}

This chapter aims to summarize the four papers contributing to this thesis. The summary is organised by first describing the purpose and research questions of each paper, followed by a description of the findings of the paper and how it contributes to the thesis.

\subsection{Summary of paper 1}

The purpose of paper 1 is to investigate the state of SCM, logistics and TPL in construction and give new understanding of why the full potential of the concepts are not yet reached. This is achieved through a systematic literature review and by answering the following research questions:

RQ1: How has research on SCM, logistics and TPL in the construction industry evolved over time?

RQ2: How has SCM, logistics, and TPL been utilized in the construction industry?

RQ3: Why has the adoption of SCM, logistics, and TPL not reached its full potential in construction?

Paper 1 also strives to highlight how to reach further in the adoption of SCM, logistics and TPL in construction by answering the following research question:

RQ4: What is needed in order for the construction industry to reach further in adopting SCM, logistics, and TPL?

Through the extensive investigation of literature on SCM, logistics, and TPL in the construction industry, paper 1 has provided insight into how the interest in SCM and logistics in construction has increased. However, paper 1 also shows that there is confusion as to what SCM and logistics entail and how the concepts differ. Practitioners use supply chain vocabulary but are often talking about operational logistics in doing so. This implies that there is some supply chain awareness, but that supply chain maturity is still not widespread in the industry, making SCM difficult to adopt. The key to reaching more supply chain maturity is to ensure that knowledge and information is shared amongst the stakeholders. This is where TPL can play a part. TPL providers are specialists in logistics and the construction industry can benefit from their logistics knowledge while at the same time sharing their construction knowledge with TPL providers.

The contribution from paper 1 to the thesis lies primarily in the identification of the interorganizational issues of the construction industry with its temporary supply chains and that 
this leads to difficulties in adopting the long-term aims of SCM. The paper also shows that there is a non-conformity regarding what the concepts SCM and logistics entail, thus adding to the difficulty in how these concepts can be adopted to the construction industry context. Furthermore, paper 1 contributes by acknowledging that it may not be possible to go for a full adoption of SCM, but rather that implementing logistics initiatives, e.g. TPL can be a way for the industry to move towards SCM.

\subsection{Summary of paper 2}

In many large urban development projects, the use of CLS's is needed in order to alleviate some of the difficulties found in the urban transport system, e.g. shared infrastructure leading to congestion, pollution and noise restrictions, and accessibility issues. There is however, a lack of research regarding governance strategies for CLS's. The studies that exist have all been of an explorative nature, not providing suggestions of how to organize construction logistics in urban development projects, i.e. governance strategy guidelines considering different stakeholder perspectives. Therefore, the purpose of this paper is to develop such guidelines. To respond to the purpose two research questions are put forward:

RQ1: What are the experiences of different stakeholders (the municipality, the developers, the TPL provider and the main contractors) of using a CLC in a large urban development project?

RQ2: Based on the experiences of the different stakeholders, what are important aspects to consider when developing construction logistics governance strategies in urban development projects?

One of the main contributions of the paper is that even with the best intentions, a CLS is more likely to be perceived as a good solution if the perspectives of the users are considered early on in the governance strategy design process. Paper 2 also shows that in order for a CLS to work properly, the responsibility of all stakeholders needs to be clearly stipulated and communicated to the right stakeholders. Regulations developed on the strategic level early on in the project, need to be flexible to handle the operational reality later in the project. All stakeholders realize that some sort of joint CLS is likely to be an everyday occurrence in urban development projects in a not so distant future. How this solution is set up however, will affect the users attitude towards it. If flexibility and dialogue is part of the process, chances are that the solution is perceived as a help, rather than a hindrance.

Paper 2 contributes to the thesis by investigating stakeholder experiences connected to the utilization of a CLS in a large urban development project. Figure 17 highlights the experiences found in paper 2 . 


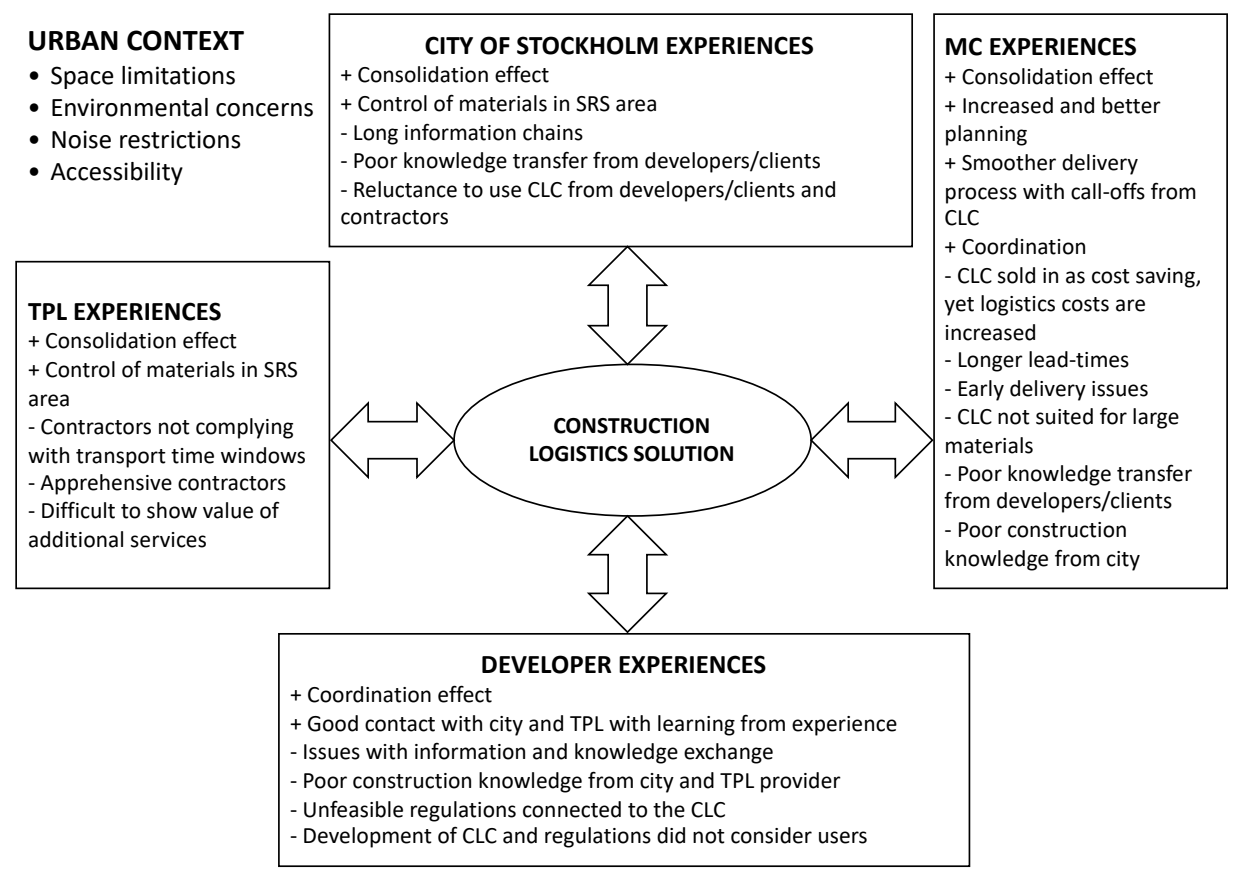

Figure 17 - The stakeholder experiences of utilizing a CLC

\subsection{Summary of paper 3}

The purpose of paper 3 is to investigate the possible benefits, alongside with the effect on costs, that can be realized when employing CLS's. This is achieved through a case study of a large construction project that has implemented and used a CLS. The purpose is met through answering the following research questions:

RQ1: What benefits are realized when utilizing a TPL solution?

RQ2: What costs are affected by the use of a TPL solution?

RQ3: How does the logistics maturity of supply chain members affect the implementation of TPL?

The paper shows that adding a TPL solution can streamline the logistics process for urban construction projects. One of the goals in utilizing a TPL solution is to reduce the delivery traffic to the construction site by consolidating smaller deliveries. A terminal-based solution can achieve this. A terminal also provides the possibility to reduce material stored at site, reducing the number of material related incidents and accidents. However, adding a new node in the delivery network that also acts as a storage point will add costs for warehousing, storage, handling, and administration. The key is to offset the additional costs against the efficiency gains. The implementing party needs to show benefits from the solution and work to increase the logistics knowledge for the suppliers and sub-contractors that are part of the construction project. Otherwise, they stand the risk of adding costs to 
the project without being able to harvest the benefits and thereby being able to reduce the total cost of the project.

The main contribution to the thesis from paper 3 is in the identification of possible benefits and issues, and what costs are affected by the introduction of a CLS. Table 4 highlights the contribution of paper 3 to the thesis.

Table 4 - The identification of benefits, issues, and cost effects of CLS'S

\begin{tabular}{|c|c|c|c|}
\hline \multicolumn{2}{|r|}{ Benefits } & \multirow[b]{2}{*}{$\begin{array}{l}\text { Issues } \\
\text { - Terminal layout not } \\
\text { suited for construction } \\
\text { materials } \\
\text { - Added a node in the } \\
\text { delivery network } \\
\text { - Unfamiliar concept in } \\
\text { the construction context } \\
\text { - Non-standardised } \\
\text { labelling }\end{array}$} & \multirow[b]{2}{*}{$\begin{array}{l}\text { Cost effect } \\
\text { Added: } \\
\text { - Increased cost for } \\
\text { materials relocation } \\
\text { - Cost for additional } \\
\text { delivery node added to } \\
\text { project budget } \\
\text { Reduced: } \\
\text { - Possible reduction in } \\
\text { transport costs }\end{array}$} \\
\hline Terminal & $\begin{array}{l}\text { - Some consolidation and } \\
\text { coordination of deliveries } \\
\text { - Fewer third-party } \\
\text { disturbances } \\
\text { - Less material on-site } \\
\text { - Material buffer to cope with } \\
\text { production changes } \\
\text { - Option to call off JIT- } \\
\text { deliveries }\end{array}$ & & \\
\hline $\begin{array}{l}\text { On-site } \\
\text { materials } \\
\text { handling }\end{array}$ & $\begin{array}{l}\text { - Dedicated personnel for } \\
\text { materials receiving } \\
\text { - Better utilization of the } \\
\text { construction site and } \\
\text { equipment with materials } \\
\text { handling off-hours. } \\
\text { - Time freed up for craftsmen } \\
\text { - Material available for } \\
\text { craftsmen when needed } \\
\text { - Cleaner and more } \\
\text { structured construction site } \\
\text { - Fewer work-related } \\
\text { accidents } \\
\text { - Follow-up of deliveries and } \\
\text { delivery deviations }\end{array}$ & $\begin{array}{l}\text { - Increased planning and } \\
\text { coordination } \\
\text { - Unfamiliar concept in } \\
\text { the construction context } \\
\text { - Non-standardised } \\
\text { labelling } \\
\text { - Planning } \\
\text { documentation not } \\
\text { always correct } \\
\text { - Process and equipment } \\
\text { related deviations add to } \\
\text { work-load for on-site } \\
\text { materials handling team }\end{array}$ & $\begin{array}{l}\text { Added: } \\
\text { - Difficult to offset } \\
\text { costs for materials } \\
\text { handling in sub- } \\
\text { contractor agreements } \\
\text { - Planning } \\
\text { documentation and } \\
\text { labelling issues leads } \\
\text { to extra work and } \\
\text { added costs } \\
\text { Reduced: } \\
\text { - Possible reduction in } \\
\text { materials handling } \\
\text { costs } \\
\text { - Increased } \\
\text { productivity reduces } \\
\text { cost of operations }\end{array}$ \\
\hline $\begin{array}{l}\text { Planning } \\
\text { system and } \\
\text { process }\end{array}$ & $\begin{array}{l}\text { - Standardised process } \\
\text { - Cloud-based system } \\
\text { granting easy access for all } \\
\text { parties } \\
\text { - Visibility of all planned } \\
\text { deliveries } \\
\text { - Coordination of all } \\
\text { materials stakeholders } \\
\text { - More proactive planning }\end{array}$ & $\begin{array}{l}\text { - Unfamiliar process for } \\
\text { sub-contractors } \\
\text { - Initial issues with } \\
\text { functionality } \\
\text { - Process not adhered to } \\
\text { by all, leading to issues } \\
\text { on-site }\end{array}$ & $\begin{array}{l}\text { Added: } \\
\text { - Initial investment for } \\
\text { planning system } \\
\text { - Administrative costs } \\
\text { increase as process is } \\
\text { dependent on updated } \\
\text { delivery plans } \\
\text { Reduced: } \\
\text { - Reduces costs for } \\
\text { tracking and tracing } \\
\text { deliveries and } \\
\text { materials }\end{array}$ \\
\hline
\end{tabular}




\subsection{Summary of paper 4}

When a CLC is introduced into the material flow, the cost for this additional node becomes visible through the invoices sent by the TPL provider. This is a new situation for developers and contractors that they are not used to budget for. To make construction logistics costs tangible, an activity-based costing ( $\mathrm{ABC}$ ) approach can be adopted. However, this approach has not yet been utilized in the cost analysis of CLS's. The purpose of this paper is thus to analyse what activities and costs a CLC entails in order to propose a model for calculating said costs and discussing how the inclusion of a CLC affects site organisations and logistics activities carried out within the construction project. The purpose is fulfilled with the aid of the following research questions:

RQ1: How can activity-based costing be used to model the main contractors cost of utilizing a construction logistics centre?

RQ2: How do the average CLC costs of three projects with different levels of logistics organization compare to the average costs of utilizing the CLC in Stockholm Royal Seaport?

Paper 4 makes a contribution in presenting an ABC breakdown of the use of a CLC in a construction supply chain (Table 5) as well as calculating the cost of using the services of a CLC in relation to project cost. One conclusion is that it is possible to develop an $\mathrm{ABC}$ model for CLS's and that it is possible to show a cost of utilizing the studied solution. What the $\mathrm{ABC}$ breakdown shows is that the CLC add a number of cost driving activities to the construction supply process, that would not have been there if direct deliveries were used, i.e. transport to CLC, operations in CLC and transport from CLC. Paper 4 contributes to thesis through the $\mathrm{ABC}$ modelling by showing that the method is valid for making construction logistics costs tangible. Furthermore, the paper has shown that the overall cost of utilizing a CLC is very small compared to the total project cost. Paper 4 also contributes through the discussion regarding how the site organization impacts the possibilities of utilizing the CLS and thereby the cost of using the solution. 
Table 5 - Identified activities and resources in the material delivery process using a CLC

\begin{tabular}{|c|c|c|}
\hline Logistics process & Activity & Resources \\
\hline Direct transport & $\begin{array}{l}\text { Transport } \\
\text { Piloting }\end{array}$ & $\begin{array}{l}\text { Lorry driver } \\
\text { Lorry } \\
\text { Stow materials } \\
\text { Administrative labour }\end{array}$ \\
\hline Transport to $C L C$ & $\begin{array}{l}\text { Loading } \\
\text { Transport }\end{array}$ & $\begin{array}{l}\text { Administrative labour } \\
\text { Handling labour } \\
\text { Handling equipment } \\
\text { Lorry driver } \\
\text { Lorry } \\
\text { Stow materials }\end{array}$ \\
\hline CLC operations & $\begin{array}{l}\text { Warehousing } \\
\text { Receiving } \\
\text { Quality } \\
\text { Registration } \\
\text { Storing } \\
\text { Relocation } \\
\text { Planning } \\
\text { Picking } \\
\text { Sequencing }\end{array}$ & $\begin{array}{l}\text { Cost of rent } \\
\text { Capital cost } \\
\text { Handling labour } \\
\text { Handling equipment } \\
\text { Inspection labour } \\
\text { Administrative labour } \\
\text { Handling labour } \\
\text { Handling equipment } \\
\text { Storage cost } \\
\text { Opportunity cost loss } \\
\text { Handling labour } \\
\text { Handling equipment } \\
\text { Administrative labour } \\
\text { Handling labour } \\
\text { Handling equipment } \\
\text { Handling labour } \\
\text { Handling equipment }\end{array}$ \\
\hline Transport from CLC & $\begin{array}{l}\text { Loading } \\
\text { Announcing } \\
\text { Transport }\end{array}$ & $\begin{array}{l}\text { Administrative labour } \\
\text { Handling labour } \\
\text { Handling equipment } \\
\text { Administrative labour } \\
\text { Lorry driver } \\
\text { Lorry } \\
\text { Stow materials }\end{array}$ \\
\hline
\end{tabular}




\section{Results}

This chapter provides answers to the research questions, as well as a discussion on the purpose of the thesis. Finally, some summarising propositions are put forth.

\subsection{Answering the research questions}

How are different stakeholders in the construction industry affected by construction logistics solutions?

When CLS's are introduced in e.g. urban development projects, different stakeholders will inevitably be affected in different ways (Caldwell, et al., 2009; Teisman and Klijn, 2004). From an inter-organizational point-of-view, what CLS's do is that they break up old structures of coordination by adding an additional node and stakeholder into the supply chain. What paper 1 highlights is that the construction industry is characterized by temporary supply chains along with loose and tight couplings (see Figure 2) (Bankvall, et al., 2010; Dubois and Gadde, 2002; London and Kenley, 2001). These characteristics have led to difficulties for the industry to wholly adopt SCM and logistics (Bankvall, et al., 2010; Fernie and Tennant, 2013; Fernie and Thorpe, 2007). Similarly, one finding from paper 2 is that the studied stakeholders are unsure of how to relate to and utilize the logistics solution (cf. Fernie and Tennant, 2013; Fernie and Thorpe, 2007). Partly this is due to the poor knowledge transfer found amongst the stakeholders of the CLS (see Figure 17). To reduce this information asymmetry, the initiating party needs to align the interests of different stakeholders (Boissinot and Paché, 2011) through clearly designed and communicated governance strategies for how the CLS is to be utilized (Williamson, 1999; Jereb, 2017). Without properly explaining the solution and its goal, adding the CLS into the construction supply chain will, as found in paper 2, lead to apprehensiveness in utilizing the solution. There is also an increased risk for conflicts and non-compliance with the regulations set (cf. Norrman and Henkow, 2014). One such example from paper 2 is the avoidance strategies utilized by some contractors to get around mandatory planning and gate passage bookings.

The major drawback with the introduction of the CLS in paper 2 seems to be the nonalignment of stakeholder goals and the CLS's goal. From the municipal perspective, the CLS has decreased disturbances on the urban transport system which was a major goal (cf. Carlsson and Janné, 2012; Dablanc, 2007; Russo and Comi, 2010). The contractors on the other hand, wants a smooth delivery process (cf. Ekeskär and Rudberg, 2016; Lindén and Josephson, 2013) and by adding this new node in the delivery system, they experience that deliveries are slower and costlier. This adds an apprehensiveness in utilizing the CLS from 
the contractors' side. If done correctly however, the utilization of CLS's can reduce the number of interruptions for craftsmen who have to receive material deliveries as part of their work tasks (cf. Ekeskär and Rudberg, 2016; Lindén and Josephson, 2013). Paper 2 also shows that one of the main benefits experienced by the stakeholders is the coordination of material deliveries.

The stakeholders in paper 2 are expecting CLS's to be an everyday occurrence in future urban development projects. In essence, this implies that in the long run the context in which they work will change as CLS's become more widespread. This means that, providing these predictions come true, construction stakeholders will be "forced" to address coordination through CLS's in order to ensure efficient material deliveries. This can open up for more acceptance and understanding of logistics and SCM in construction (cf. Fernie and Tennant, 2013; Fernie and Thorpe, 2007). To summarize;

- The stakeholders studied in paper 2 experience that coordination of material deliveries has improved compared to traditional construction projects.

- Introducing a CLS will however add a new node and stakeholder to whom the existing stakeholders must relate and plan for.

- One problem has been in the inter-organizational relationships with the new stakeholder/node introduced into the supply chain as the different stakeholders have been unsure of how to relate to and utilize the logistics solution.

- The utilization of CLS's can reduce the number of interruptions for craftsmen who have to receive material deliveries as part of their work tasks.

- In the long run, the effect that CLS's have on construction stakeholders is that they are preparing for a new future context in urban construction. This preparation can in turn lead to more acceptance and understanding of logistics and SCM in the construction industry context.

How will the use of construction logistics solutions affect material flows and costs in urban construction projects?

Utilizing CLS's can improve how construction logistics is managed, coordinated and executed (Agapiou, et al., 1998a). Depending on the CLS used, however, the material flows will be affected differently (cf. Lundesjo, 2011; Sundquist, et al., 2017). From papers 3 and 4 , it is evident that introducing a terminal-based CLS into the construction supply chain will, in effect, add a new node that comes with a cost but also with some benefits. The consolidation effect is of course a benefit of the terminal-based CLS (cf. Browne, et al., 2005; Lundesjo, 2011). In the cases reported in papers 3 and 4, the CLS's also offered the opportunity of storing materials for later delivery. These aspects lead to greater control of material flows (cf. Brunge, 2013; Lundesjo, 2010, 2011). In the terminal case, deliveries are re-routed to the terminal for consolidation (cf. Browne, et al., 2005; Lundesjo, 2011), but also for coordinating when and how the final delivery to site is performed (cf. Sundquist, et al., 2017; Lindén and Josephson, 2013). With a checkpoint-style CLS, the consolidation effect is lacking as the whole concept builds on just-in-time deliveries that must be planned for and coordinated accordingly (cf. Sundquist, et al., 2017; Lindén and Josephson, 2013; 
Ekeskär and Rudberg, 2016). A big drawback seen in papers 3 and 4 is that when this new node is added, delivery times are prolonged as the deliveries have to go through the new node where materials are received, handled, re-loaded, and then delivered to site. Again, this demands more and better planning of material flows (cf. Ekeskär and Rudberg, 2016; Sundquist, et al., 2017; Thunberg and Fredriksson, 2018; Thunberg and Persson, 2014). Thus, one of the great effects of CLS's is that construction companies, i.e. contractors and installation firms, have to start planning their material deliveries more carefully. In the long run this leads to better control of material deliveries.

When it comes to the cost aspects, adding these CLS's will come with a cost that someone eventually will have to pay for. In paper 3, the costs that were affected by the CLS were identified, and the major change in cost structure for contractors were the cost of the terminal and its warehousing function (cf. Zeng and Rossetti, 2003; Shakantu, et al., 2003; Engblom, et al., 2012; Stock and Lambert, 2001). However, there were indications that the cost for transports could actually be lowered as instead of multiple vehicles arriving to site, one consolidated delivery could take care of the last leg of the journey (see Table 4) (Ying, et al., 2014; Vidalakis, et al., 2011; Vidalakis, et al., 2013). On site, this can reduce the cost of non-productive time as deliveries are coordinated and consolidated, meaning that the craftsmen will not be interrupted as often to receive materials as in the traditional setup (cf. Ekeskär and Rudberg, 2016; Lindén and Josephson, 2013). However, the costs of implementing and utilizing CLS's are still a source of worry for many construction companies as the logistics costs are to a large extent intangible (Ying, et al., 2014; Fang and Ng, 2011). Paper 4 provides an initial cost modelling effort through activity-based costing (see Table 5, Figure 18), and from this it was shown that there is a way to take control of the costs of CLS's. Identifying the cost drivers allow construction companies the chance of seeing where costs occur, and to plan for the logistics costs already when planning the construction project (Vasiliauskas and Jakubauskas, 2007; LaLonde and Pohlen, 1996; Lin, et al., 2001). To summarize;

- A terminal-based CLS allows for a consolidation effect but also for storage of materials.

- However, terminal-based CLS's also leads to prolonged delivery times due to the rerouting of deliveries through the terminal.

- CLS's forces construction companies, i.e. contractors and installation firms, to plan their material deliveries more carefully, leading to better control of material deliveries.

- Adding a CLS into the construction supply chain will add costs for administration, material handling, and planning.

- One way of identifying the CLS costs is through ABC modelling of the material flow when utilizing CLS's. This can help the construction companies take control of costs and more importantly, plan for the costs of logistics in construction projects. 




Figure 18 - ABC breakdown of utilizing a CLC

\subsection{Discussing the purpose}

The purpose of this thesis is to explore how construction logistics solutions can be used as a means to coordinate material flows to ensure efficient construction and reduce disturbances on the urban transport system. This thesis' contextual considerations are the construction industry context as well as the urban environment and transport system. As noted previously, goods transports and logistics in the urban transport system has been treated as a problem for the logistics industry to solve (Ballantyne, et al., 2013). By introducing CLS's, the construction industry and cities are taking a greater responsibility for the impact of these deliveries than before. However, when introducing a CLS in an urban construction or development project, it is inevitably going to affect the urban transport system (cf. Carlsson and Janné, 2012; Dablanc, 2007; Russo and Comi, 2010; Caldwell, et al., 2009). The urban transport system today needs to cater to public and private transport, goods deliveries, and of course construction material flows (cf. Carlsson and Janné, 2012; Dablanc, 2007; Russo and Comi, 2010).

Construction in urban areas can disrupt the balance of the urban transport system both through the actual construction site, but also through the construction material flows. This can lead to disturbances and unnecessary friction with residents and businesses, i.e. third 
parties, in that the risk for congestion, noise, pollution and accidents increase (cf. Anderson, et al., 2005; Behrends, et al., 2008; Bretzke, 2013; Dablanc, 2007, 2008). The goal must thus be to allow everyday urban life to continue in an as normal way as possible, as well as ensuring that construction materials reach its destination in a satisfactory way. In paper 2 it was found that one of the main benefits experienced was the coordination of deliveries and stakeholders connected to the CLS. By employing a CLS in the urban transport system, third-party disturbances from construction material deliveries can be reduced as the coordination and possible consolidation of material flows can reduce the number of delivery vehicles going to site (cf. Anderson, et al., 2005; Behrends, et al., 2008; Bretzke, 2013; Dablanc, 2007, 2008). The consolidation effect of the CLS in paper 2 was estimated to be some 40-60 per cent of the deliveries of traditional construction projects. This implies that the reduction in number of delivery vehicles should also be noted in the urban transport system. However! This is true, provided that the context of the urban environment has been taken into consideration when planning for and designing the CLS (cf. Lundesjo, 2010, 2011). As was found in paper 2 , the location of the CLS affects the outcome of the solution. If a terminal-based CLS is located next to the construction site, the consolidation effect may to some extent be lost for the urban transport system as delivery vehicles still have to travel to the CLS. If it is located further away from the construction site, chances are that deliveries to the CLS can be routed away from the city, thus adding to the reduction of stress put on the urban transport system.

Whether it is a consolidated delivery, or a directly routed just-in-time delivery is in a coordinative sense of less importance; both types have to be planned as to allow for materials to be at site when needed (cf. Ekeskär and Rudberg, 2016; Sundquist, et al., 2017; Thunberg and Fredriksson, 2018). This, however, also implies that the recipients of the deliveries have to plan material deliveries, i.e. their procurement, in advance as adding a new node in the supply chain will lead to prolonged delivery times (cf. Thunberg and Fredriksson, 2018; Thunberg and Persson, 2014). Paper 2 and 3 find however, that if setup correctly, the utilization of CLS's can reduce the number of interruptions for craftsmen who have to receive material deliveries as part of their work tasks (cf. Ekeskär and Rudberg, 2016; Sundquist, et al., 2017). This can in a wider perspective also lead to better time keeping in construction projects (cf. Ekeskär and Rudberg, 2016; Sundquist, et al., 2017).

When designing the CLS, the industry context with temporary supply chains with many individual stakeholders (Dubois and Gadde, 2002; Karrbom Gustavsson and Hallin, 2015; London and Kenley, 2001; Segerstedt and Olofsson, 2010) must also be taken into consideration. For many of the stakeholders in the construction supply chain, the use of a CLS is something novel that they are unfamiliar with. As seen in papers 1 and 2 , if the CLS is not properly introduced and explained early on in the construction project, adding a new logistics practice into the supply chain can increase the uncertainty and apprehension of different stakeholders. Here it is also important to consider the different interorganizational couplings of the construction industry (Dubois and Gadde, 2002). It is not necessarily so that the parent company level is the correct level to communicate the CLS and its corresponding governance strategy to (Dubois and Gadde, 2002). To some extent, 
it is the project level that holds the greater power in the company-project relationship and it is the project that will be subjected to the CLS. As papers 2 and 3 highlight, it is of great importance that the initiator of the CLS takes the lead and creates an environment where all users of the solution are striving towards the same goal (Mentzer, et al., 2001). Thus, when designing the CLS, it is important to involve representatives from the project level to solidify the understanding from those stakeholders who will utilize the CLS on an operative level (Boissinot and Paché, 2011; Caldwell, et al., 2009). This would also allow the initiator to take the needs of the specific projects into consideration. The CLS must be associated with some sort of control mechanisms in order to align the practices of the different users (Caldwell, et al., 2009). In the case of CLS's, formal control mechanisms are needed, stipulating the utilization of the CLS in contractual agreements. Here it is vital that the initiating stakeholder clearly states what the goal of the CLS is and how the associated governance strategy will help in achieving this goal (Boissinot and Paché, 2011; Caldwell, et al., 2009).

As a summary, the research in this thesis has shown that;

- CLS's have a huge role to play in the coordination of different construction stakeholders. This new node will "force" stakeholders to address coordination issues to ensure efficient material deliveries. It is however of great importance that the initiator of the solution creates understanding amongst stakeholders so that all stakeholders strive towards the same goal. This will take an attitude adjustment towards more collaboration in the supply chain.

- By introducing a CLS into the construction supply chain, the initiator adds a new node that the stakeholders have to take into consideration when planning for construction projects or material flows. This will to some extent prolong the material delivery planning horizon for the contractors as a new node will add to the delivery time.

- Urban construction affects the everyday urban life both through the construction site, and the material flows. Adding a CLS can reduce unnecessary impact on other stakeholders in the urban transport system in that coordinated material flows can lead to a reduction in the amount of material delivery vehicles that travels to site.

- When designing the CLS and the corresponding governance strategy, the initiator must take the construction industry context into consideration. The temporary nature of the construction supply chain means that the initiator must strive to create a stable solution that takes different stakeholder needs into consideration as they enter the supply chain.

- The initiator must make sure to set clear regulations for the CLS early on to reduce apprehensiveness from the users of the CLS. If users are consulted on the function, they are more likely to be more accepting of the solution. 


\section{Contribution and future research}

This final chapter presents the thesis' scientific and practical contributions, as well as suggestions for future research.

\subsection{Contribution}

The four papers in this compilation thesis together make up the conclusions and contributions of the thesis. This research has been of an explorative nature in that it investigates CLS's in urban areas. However, this thesis is far from all-encompassing when it comes to CLS's in urban areas. The research presented in this thesis do provide insights into how CLS's can be used to coordinate construction stakeholders and material flows to construction sites and govern urban transport flows. It also provides some insight into interorganizational considerations to take when initiating these CLS's.

The main contribution of this thesis lies in the exploration of how dedicated CLS's can be used as a means to coordinate material flows to ensure efficient construction and reduce disturbances on the urban transport system. This study has shown that the use of CLS's will "force" stakeholders to address coordination issues to ensure efficient material deliveries. As such, the main coordinative effect resides in the governance strategy and mechanisms that are connected to the CLS. However, as CLS's are a rare phenomenon in construction, the contribution of this thesis to the governance of CLS's should be seen as a first step towards creating a wider understanding of how, why and through what measures the CLS governance should be developed. This thesis shows that if the regulations set for the CLS makes it difficult to utilize the CLS, chances are that some stakeholders will try to bypass the rules. Here it is vital that the initiating stakeholder clearly states what the aim of the CLS is and creates an environment in which all stakeholders strive towards the same goal.

This thesis further contributes by highlighting what the effects of CLS's are on material flows and logistics costs. As discussed in chapter 5.1, introducing a CLS can give a multitude of benefits such as better control of material flows and coordination, as well as prerequisites for a more collaborative construction environment. With a terminal-based CLS, the main benefits lie in the consolidation effect and the opportunity of storing materials for later call-offs, giving better control of how and when materials are delivered to site. The checkpoint solution lacks these benefits but provides the coordinating effect of the how and why as it is based on just-in-time deliveries. The thesis also discusses some drawbacks of CLS's in that they demand more planning, i.e. administrative time. The major drawback found however, is that of the prolonged delivery time in the terminal-based CLS case. Adding a compulsory node for materials to pass through will add to the total delivery 
time. Here the thesis contributes by suggesting that CLS users must adapt to this situation and start planning their material flows with longer planning horizons.

Furthermore, the research contributes by investigating how to allocate costs of CLS's and make them tangible. By utilizing a well-known technique, i.e. activity-based costing, the research adds to the applicability of $\mathrm{ABC}$, as well as opening up opportunities for further studies of the identified CLS cost components. The research presented in the thesis suggests that utilizing CLS's in reality divides the material delivery process into four subprocess and provides an initial $\mathrm{ABC}$ modelling effort of the four identified sub-processes (see Table 5 and Figure 18). This thesis also shows through the studied cases that the contribution of a CLS to the overall cost does not necessarily have to be that big. When developing or implementing a CLS however, the cost should be discussed in conjunction with the potential benefits of the solution and a plan for offsetting the added costs of CLS's against the potential benefits needs to be developed.

Finally, the research in this thesis finds that the utilization of a CLS can reduce the negative impact from construction material flows on the urban transport system through the coordination effects that arise. This is, however, under the prerequisite that the solution is designed with this in mind and takes the urban transport system context into consideration. If a CLS is located next to the development area or construction site, there is a risk that the sought-after effect of reducing disturbances on the urban transport system is lost. The coordination within the construction project or development area may still occur, but as material deliveries still pass through the city to get to the CLS, the sought-after benefits are to some extent lost. The governance strategy connected to the CLS should in these cases also specify which routes are unsuitable to use. This again place demands on collaboration amongst municipal administrations, developers, contractors, and CLS operators in order to ensure that the disturbances to the urban transport system are reduced.

\subsection{Future research}

This licentiate thesis is part of doctoral research project focusing on construction logistics solutions and their role in governing and coordinating material flows in urban development projects. Being primarily based on single case study research, this thesis does not offer an all-encompassing view of CLS's. It does however, provide interesting insights into how CLS's can affect the urban transport system and the material flows to construction sites. As such, this thesis is to some extent a way to draw up directions for the future of this research project. Listed below are suggestions for future research. Some of these suggestions will be carried out within the continuation of the doctoral project, whereas some suggestions are left to other researchers to address.

- Currently, there are question marks regarding who the initiating party of CLS's should be. In this research, examples are given on both municipality and construction company initiated CLS's. Both examples have had similar goals and results, but are these solutions developed in a similar vein as this is the most common way of doing it? As is discussed in chapter 5.1, different stakeholders have different interests and goals with 
their operations in connection to the CLS. Thus, it would be of interest to investigate how different construction industry stakeholders can have varying goals with a CLS and how the goals affect the CLS being developed. It would also be of interest to look into what stakeholder should have the operative responsibility for running a CLS. A framework for how CLS's are developed could be a good outcome.

- Developing a CLS is only the start, it also has to be implemented. How can construction industry stakeholders come together with a common vision for the CLS? This research should include identification of important stakeholders and suggest how they can be brought together early on in the process as it has been shown in this thesis that the early involvement has been lacking. What incentives are needed in order to bring stakeholders together? This research direction should also look into what governance measures are needed. How can the governance strategy take into consideration that different contractors have different needs during different construction phases? Without rules and regulations, the CLS may not achieve the coordination effect needed. What type of inter-organizational relationships and/or agreements are needed?

- Another suggestion is to look at the more technical aspects of introducing a CLS. What different types of CLS's are there? Are all types of CLS's suitable for all construction contexts? What different effects will different CLS's bring for the construction industry as well as the surrounding society? This research direction should look deeper into the effect that different CLS's have on material flows. This thesis primarily discusses CLC's and as such, the conclusions regarding the prolonged planning horizons, added costs, and material control found in chapter 5.1 and 5.2 are strongly linked to terminalbased solutions. Are the effects similar for other types of CLS's?

- Another important aspect of CLS's that needs to be developed further is the effect that construction material deliveries have on the urban transport system. In this thesis, the urban transport system has been treated as a contextual factor, but it is important to dig deeper into this context and investigate how material delivery transports affect other urban transports. One proposal is to look into traffic-flow modelling to investigate the effect that CLS's and their location has on urban traffic.

- This research project has taken four different stakeholder perspectives into consideration; contractors, developers, municipalities, and CLS operators. Future research should take other stakeholder perspectives into considerations as well. Some suggestions are construction material suppliers, transporters, and residents. This would create a wider understanding for how CLS's affect the urban environment. 


\section{References}

Agapiou, A., Clausen, L. E., Flanagan, R., Norman, G. \& Notman, D. 1998a. The role of logistics in the materials flow control process. Construction Management and Economics, $16,131-137$.

Agapiou, A., Flanagan, R., Norman, G. \& Notman, D. 1998b. The changing role of builders merchants in the construction supply chain. Construction Management and Economics, 16, 351-361.

Aguirre, A. B., Hennies, W. T. \& Marks, A. 2010. Innovative logistics for the transportation of sand and gravel in Brazil. International Journal of Logistics Systems and Management, 7, 490-506.

Allen, J., Browne, M., Woodburn, A. \& Leonardi, J. 2014. A review of urban consolidation centres in the supply chain based on a case study approach. Supply Chain Forum, 15, 100-112.

Anderson, S., Allen, J. \& Browne, M. 2005. Urban logistics - How can it meet policy makers' sustainability objectives? Journal of Transport Geography, 13, 71-81.

Ballantyne, E. E. F., Lindholm, M. \& Whiteing, A. 2013. A comparative study of urban freight transport planning: addressing stakeholder needs. Journal of Transport Geography, 32, 93-101.

Bankvall, L., Bygballe, L. E., Dubois, A. \& Jahre, M. 2010. Interdependence in supply chains and projects in construction. Supply Chain Management: An International Journal, 15, 385-393.

Behrends, S., Lindholm, M. \& Woxenius, J. 2008. The Impact of Urban Freight Transport: A Definition of Sustainability from an Actor's Perspective. Transportation Planning and Technology, 31, 693-713.

Benson, J. K. 1975. The Interorganizational Network as a Political Economy. Administrative Science Quarterly, 20, 229-249.

Berglund, M., van Laarhoven, P., Sharman, G. \& Wandel, S. 1999. Third-Party Logistics: Is There a Future? The International Journal of Logistics Management, 10, 59-70.

Björklund, M., Abrahamsson, M. \& Johansson, H. 2017. Critical factors for viable business models for urban consolidation centres. Research in Transportation Economics, 64, 36-47.

Boissinot, A. \& Paché, G. 2011. Opportunism control in exchange relationships: Lessons from the French logistics industry. Problems and Perspectives in Management, 9, 71-77. 
Bolumole, Y. A. 2001. The Supply Chain Role of Third-Party Logistics Providers. The International Journal of Logistics Management, 12, 87-102.

Bretzke, W. R. 2013. Global urbanization: A major challenge for logistics. Logistics Research, 6, 57-62.

Browne, M., Sweet, M., Woodburn, A. \& Allen, J. 2005. Urban Freight Consolidation Centres Final Report. In: Transport Studies Group, U. o. W. (ed.). University of Westminster.

Brunge, K. 2013. Förbättrad logistik för byggmaterial i Norra Djurgårdsstaden. Master of Science Master of Science, Royal Institute of Technology.

Caldwell, N. D., Roehrich, J. K. \& Davies, A. C. 2009. Procuring complex performance in construction: London Heathrow Terminal 5 and a Private Finance Initiative hospital. Journal of Purchasing and Supply Management, 15, 178-186.

Carlsson, C.-M. \& Janné, M. 2012. Sustainable Urban Distribution in the Øresund Region. In: Carlsson, C.-M., Emtairah, T., Gammelgaard, B., Vestergaard Jensen, A. \& Thidell, Å. (eds.) Rethinking Transport in the Øresund Region: Policies, Strategies and Behaviours. Lund: Lund University.

Christopher, M. 2011. Logistics \& Supply Chain Management, Dorchester, United Kingdom, Pearson Education Limited.

Cooper, R. \& Kaplan, R. S. 1991. Profit priorities from activity-based costing. Harvard business review, 69, 130-135.

Cronin, P., Ryan, F. \& Coughlan, M. 2008. Undertaking a literature review: a step-bystep approach.

Dablanc, L. 2007. Goods transport in large European cities: Difficult to organize, difficult to modernize. Transportation Research Part A: Policy and Practice, 41, 280-285.

Dablanc, L. 2008. Urban Goods Movement and Air Quality Policy and Regulation Issues in European Cities. Journal of Environmental Law, 20, 245-266.

Danielson, P. 2007. Terminalisering hos $J M A B$. Master of Science Master of Science, Luleå University of Technology.

Dubois, A. \& Gadde, L.-E. 2000. Supply strategy and network effects - Purchasing behaviour in the construction industry. European Journal of Purchasing and Supply Management, 6, 207-215.

Dubois, A. \& Gadde, L.-E. 2002. The construction industry as a loosely coupled system: implications for productivity and innovation. Construction Management and Economics, 20, 621-631.

Egan, J. 1998. Rethinking construction. London, United Kingdom: Department of Trade and Industry. 
Eisenhardt, K. M. 1989. Building Theories from Case Study Research. The Academy of Management Review, 14, 532-550.

Ek, M. 2008. Effektivisering av arbetsplatslogistik: En fallstudie vid NCC Construction Stockholm/Mälardalen. Master of Science Master of Science, Luleå Technical University.

Ekeskär, A. 2016. Exploring Third-Party Logistics and Partnering in Construction: A Supply Chain Management Perspective. Licentiate, Linköping University.

Ekeskär, A. \& Rudberg, M. 2016. Third-party logistics in construction: the case of a large hospital project. Construction Management and Economics, 34, 174-191.

Ellram, L. M. 1995. Total cost of ownership: an analysis approach for purchasing. International Journal of Physical Distribution \& Logistics Management, 25, 4-23.

Emerson, R. M. 1962. Power-Dependence Relations. American Sociological Review, 27, $31-41$.

Engblom, J., Solakivi, T., Töyli, J. \& Ojala, L. 2012. Multiple-method analysis of logistics costs. International Journal of Production Economics, 137, 29-35.

Evangelista, P. \& Durst, S. 2015. Knowledge management in environmental sustainability practices of third-party logistics service providers. VINE, 45, 509-529.

Everaert, P., Bruggeman, W., Sarens, G., Anderson, S. R. \& Levant, Y. 2008. Cost modeling in logistics using time-driven ABC: Experiences from a wholesaler. International Journal of Physical Distribution \& Logistics Management, 38, 172-191.

Fadiya, O., Georgakis, P., Chinyio, E. \& Nwagboso, C. 2015. Decision-making framework for selecting ICT-based construction logistics systems. Journal of Engineering, Design and Technology, 13, 260-281.

Fang, Y. \& Ng, S. T. 2011. Applying activity-based costing approach for construction logistics cost analysis. Construction Innovation, 11, 259-281.

Fernie, S., Leiringer, R. \& Thorpe, T. 2006. Change in construction: A critical perspective. Building Research and Information, 34, 91-103.

Fernie, S. \& Tennant, S. 2013. The non-adoption of supply chain management. Construction Management and Economics, 31, 1038-1058.

Fernie, S. \& Thorpe, A. 2007. Exploring change in construction: supply chain management. Engineering, Construction and Architectural Management, 14, 319-333.

Flyvbjerg, B. 2006. Five Misunderstandings About Case-Study Research. Qualitative Inquiry, 12, 219-245.

Fossheim, K. \& Andersen, J. 2017. Plan for sustainable urban logistics - comparing between Scandinavian and UK practices. European Transport Research Review, 9. 
Gajendran, T., Brewer, G. \& Marimuthu, M. 2013. Internationalisation of construction business and E-commerce: Innovation, integration and dynamic capabilities. Australasian Journal of Construction Economics and Building, 13, 1-17.

Gammelgaard, B. 2012. The emergence of city logistics: the case of Copenhagen's Citylogistik-kbh. International Journal of Physical Distribution \& Logistics Management, 45, 333-351.

Gibbert, M., Ruigrok, W. \& Wicki, B. 2008. What passes as a rigorous case study? Strategic Management Journal, 29, 1465-1474.

Grawe, S. J. 2009. Logistics innovation: a literature-based conceptual framework. The International Journal of Logistics Management, 20, 360-377.

Green, S. D., Fernie, S. \& Weller, S. 2005. Making sense of supply chain management: a comparative study of aerospace and construction. Construction Management and Economics, 23, 579-593.

Gríful-Miquela, C. 2001. Activity-based costing methodology for third-party logistics companies. International Advances in Economic Research, 7, 133-146.

Hadaya, P. \& Pellerin, R. 2010. Determinants of construction companies' use of webbased interorganizational information systems. Supply Chain Management, 15, 371-384.

Hamzeh, F. R., Tommelein, I. D., Ballard, G. \& Kaminsky, P. M. 2007. Logistics Centers to Support Project-Based Production in the Construction Industry. In: Pasquire, C. L. \& Tzortzopoulos, P. (eds.) 15th Annual Conference of the International Group for Lean Construction. East Lansing, Michigan, USA.

Harrison, A. \& van Hoek, R. 2011. Logistics Management \& Strategy: Competing Through the Supply Chain, Harlow, England, Pearson Education Limited.

Hertz, S. \& Alfredsson, M. 2003. Strategic development of third party logistics providers. Industrial Marketing Management, 32, 139-149.

Heskett, J. L., Glaskowsky, N. A. \& Ivie, R. M. 1973. Business logistics; physical distribution and materials management, Ronald Press Co.

Homans, G. C. 1958. Social Behavior as Exchange. American Journal of Sociology, 63, 597-606.

Hufty, M. 2011. Investigating Policy Processes: The Governance Analytical Framework (GAF). In: Wiesmann, U. \& Hurni, H. (eds.) Research for Sustainable Development: Foundations, Experiences, and Perspectices. Bern, Switzerland: University of Bern.

Janné, M. 2018. Supply Chain Management, Logistics, and Third-party logistics in Construction - A literature review. Construction Management \& Economics (under review).

Janné, M. \& Fredriksson, A. 2018a. Construction Logistics Solutions in City Development Projects. Construction Innovation (under review). 
Janné, M. \& Fredriksson, A. 2018b. Cost Modelling Construction Logistics Centres. The 30th NOFOMA Conference "Relevant Logistics and Supply Chain Management Research". Kolding, Denmark: University of Southern Denmark, Denmark.

Janné, M. \& Rudberg, M. 2017. Costs and benefits of logistics solutions in construction. 24th EurOMA conference. Edinburgh, Scotland.

Jereb, B. 2017. Mastering logistics investment management. Transformations in Business and Economics, 16, 100-120.

Jesson, J. K., Matheson, L. \& Lacey, F. M. 2011. Doing you literature review: Traditional and systematic techniques, London, United Kingdom, SAGE Publications Ltd.

Josephson, P.-E. \& Saukkoriipi, L. 2007. Waste in Construction Projects: Call for a New Approach. Gothenburg, Sweden: The Centre for Management of the Built Environment, Chalmers University of Technology.

Karlsson, C. 2009. Researching Operations Management. In: Karlsson, C. (ed.) Researching Operations Management. New York: Routledge.

Karrbom Gustavsson, T. \& Gohary, H. 2012. Boundary action in construction projects: new collaborative project practices. International Journal of Managing Projects in Business, 5, 364-376.

Karrbom Gustavsson, T. \& Hallin, A. 2015. Goal seeking and goal oriented projects trajectories of the temporary organisation. International Journal of Managing Projects in Business, 8, 368-378.

Keynes, J. M. 1936. The general theory of employment, interest and money, London : Macmillan, 1936.

Klakegg, O. J. 2009. Challenging the Interface between Governance and Management in Construction Projects. 5th Nordic Conference on Construction Economics and Organisation. Reykjavik, Iceland.

Klein, B., Crawford, R. G. \& Alchian, A. A. 1978. Vertical Integration, Appropriable Rents, and the Competitive Contracting Process. The Journal of Law \& Economics, 21, 297-326.

Kristiansen, K., Emmitt, S. \& Bonke, S. 2005. Changes in the Danish construction sector: the need for a new focus. Engineering, Construction and Architectural Management, 12, 502-511.

Lai, K.-h., Edwin Cheng, T. C. \& Yeung, A. C. L. 2004. An Empirical Taxonomy for Logistics Service Providers. Maritime Economics \& Logistics, 6, 199-219.

LaLonde, B. J. \& Pohlen, T. L. 1996. Issues in Supply Chain Costing. The International Journal of Logistics Management, 7, 1-12.

Langley, C. J. 2016. 2016 Third-Party Logistics Study: The State of Logistics Outsourcing. 
Latham, S. M. 1994. Constructing the team, HM Stationery Office London.

Lin, B., Collins, J. \& Su, R. K. 2001. Supply chain costing: an activity-based perspective. International Journal of Physical Distribution \& Logistics Management, 31, 702-713.

Lindén, S. \& Josephson, P. E. 2013. In-housing or out-sourcing on-site materials handling in housing? Journal of Engineering, Design and Technology, 11, 90-106.

Lindholm, M. 2010. A sustainable perspective on urban freight transport: Factors affecting local authorities in the planning procedures. Procedia - Social and Behavioral Sciences, 2, 6205-6216.

Lindholm, M. 2012. How Local Authority Decision Makers Address Freight Transport in the Urban Area. Procedia - Social and Behavioral Sciences, 39, 134-145.

Locatelli, G., Mancini, M. \& Romano, E. 2014. Systems Engineering to improve the governance in complex project environments. International Journal of Project Management, 32, 1395-1410.

London, K. A. \& Kenley, R. 2001. An industrial organization economic supply chain approach for the construction industry: a review. Construction Management and Economics, 19, 777-788.

Lundesjo, G. 2010. Barts Hospital, London. Banbury, Oxon, Great Britain.

Lundesjo, G. 2011. Using Construction Consolidation Centres to reduce construction waste and carbon emissions. Banbury, Oxon, Great Britain: Waste \& Resources Action Programme.

Maloni, M. J. \& Carter, C. R. 2006. Opportunities for Research in Third-Party Logistics. Transportation Journal, 45, 23-38.

Marasco, A. 2008. Third-party logistics: A literature review. International Journal of Production Economics, 113, 127-147.

Mentzer, J. T., DeWitt, W., Keebler, J. S., Min, S., Nix, N. W., Smith, C. D. \& Zacharia, Z. G. 2001. Defining Supply Chain Management. Journal of Business Logistics, 22, 125 .

Meredith, J. 1993. Theory Building through Conceptual Methods. International Journal of Operations \& Production Management, 13, 3-11.

Meredith, J. 2001. Reconsidering the Philosophical Basis of OR/MS. Operations Research, 49, 325-333.

Norrman, A. \& Henkow, O. 2014. Logistics principles vs. legal principles: frictions and challenges. International Journal of Physical Distribution \& Logistics Management, 44, 744-767.

Penrose, E. T. 1959. The theory of the growth of the firm / Edith T. Penrose, Oxford, B. Blackwell. 
Perttula, P., Korhonen, P., Lehtelä, J., Rasa, P. L., Kitinoja, J. P., Mäkimattila, S. \& Leskinen, T. 2006. Improving the safety and efficiency of materials transfer at a construction site by using an elevator. Journal of Construction Engineering and Management, 132, 836-843.

Polat, G., Arditi, D., Ballard, G. \& Mungen, U. 2006. Economics of on-site vs. off-site fabrication of rebar. Construction Management and Economics, 24, 1185-1198.

Rousseau, D. M., Manning, J. \& Denyer, D. 2008. Evidence in Management and Organizational Science: Assembling the Field's Full Weight of Scientific Knowledge Through Syntheses. The Academy of Management Annals, 2, 475-515.

Russo, F. \& Comi, A. 2010. A classification of city logistics measures and connected impacts. Procedia - Social and Behavioral Sciences, 2, 6355-6365.

Said, H. \& El-Rayes, K. 2011. Optimizing material procurement and storage on construction sites. Journal of Construction Engineering and Management, 137, 421-431.

Schmidt, G. \& Wilhelm, W. E. 2000. Strategic, tactical and operational decisions in multinational logistics networks: A review and discussion of modelling issues. International Journal of Production Research, 38, 1501-1523.

Schniederjans, M. J. \& Garvin, T. 1997. Using the analytic hierarchy process and multiobjective programming for the selection of cost drivers in activity-based costing. European Journal of Operational Research, 100, 72-80.

Segerstedt, A. \& Olofsson, T. 2010. Supply chains in the construction industry. Supply Chain Management: An International Journal, 15, 347-353.

Selviaridis, K. \& Spring, M. 2007. Third party logistics: a literature review and research agenda. The International Journal of Logistics Management, 18, 125-150.

Seuring, S. \& Gold, S. 2012. Conducting content-analysis based literature reviews in supply chain management. Supply Chain Management: An International Journal, 17, 544-555.

Seuring, S. \& Müller, M. 2008. From a literature review to a conceptual framework for sustainable supply chain management. Journal of Cleaner Production, 16, 1699-1710.

Shaharudin, M. R., Zailani, S. \& Ismail, M. 2014. Third party logistics orchestrator role in reverse logistics and closed-loop supply chains. International Journal of Logistics Systems and Management, 18, 200-215.

Shakantu, W., Tookey, J. E. \& Bowen, P. A. 2003. The Hidden Cost of Transportation of Construction Materials: An Overview. Journal of Engineering, Design and Technology, 1, 103-118.

Shapiro, J. F. 1992. Integrated Logistics Management, Total Cost Analysis and Optimization Modelling. International Journal of Physical Distribution \& Logistics Management, 22, 33-36. 
Skjoett-Larsen, T., Halldorsson, A., Andersson, D., Dreyer, H., Virum, H. \& Ojala, L. 2006. Third party logistics - a Nordic approach. International Journal of Value Chain Management, 1, 190-204.

Sobotka, A. 2000. Simulation modelling for logistics re-engineering in the construction company. Construction Management and Economics, 18, 183-195.

Stefansson, G. 2006. Collaborative logistics management and the role of third-party service providers. International Journal of Physical Distribution \& Logistics Management, 36, 76-92.

Stock, J. R. \& Lambert, D. M. 2001. Strategic Logistics Management, McGrawHill/Irwin.

Strategic Forum 2002. Accelerating Change. In: Construction, S. F. f. (ed.). London, Great Britain: Strategic Forum for Construction.

Sundquist, V., Gadde, L.-E. \& Hulthén, K. 2017. Reorganizing construction logistics for improved performance. Construction Management and Economics, 1-17.

Sveriges Byggindustrier 2010. Effektiva Byggtransporter.

Tanskanen, K., Holmström, J. \& Öhman, M. 2015. Generative Mechanisms of the Adoption of Logistics Innovation: The Case of On-site Shops in Construction Supply Chains. Journal of Business Logistics, 36, 139-159.

Teisman, G. \& Klijn, E. H. 2004. PPPs: torn between two lovers. EBF Debate, 18, $27-$ 29.

Thunberg, M. \& Fredriksson, A. 2018. Bringing planning back into the picture - How can supply chain planning aid in dealing with supply chain-related problems in construction? Construction Management and Economics, 1-18.

Thunberg, M. \& Persson, F. 2014. Using the SCOR models performance measurements to improve construction logistics. Production Planning and Control, 25, 1065-1078.

Thunberg, M., Rudberg, M. \& Karrbom Gustavsson, T. 2017. Categorising on-site problems: A supply chain management perspective on construction projects. Construction Innovation, 17, 90-111.

Titus, S. \& Bröchner, J. 2005. Managing information flow in construction supply chains. Construction Innovation, 5, 71-82.

Transport for London 2013. Construction Logistics Plan Guidance for Developers. Windsor House, London: Transport for London.

United Nations 2015. World Urbanization Prospects: The 2014 Revision. New York.

van Laarhoven, P., Berglund, M. \& Peters, M. 2000. Third-party logistics in Europe five years later. International Journal of Physical Distribution \& Logistics Management, 30, 425-442. 
van Rooijen, T. \& Quak, H. 2010. Local impacts of a new urban consolidation centre the case of Binnenstadservice.nl. Procedia - Social and Behavioral Sciences, 2, 59675979.

Varila, M., Seppänen, M. \& Suomala, P. 2007. Detailed cost modelling: a case study in warehouse logistics. International Journal of Physical Distribution \& Logistics Management, 37, 184-200.

Vasiliauskas, A. V. \& Jakubauskas, G. 2007. Principle and benefits of third party logistics approach when managing logistics supply chain. Transport, 22, 68-72.

Vidalakis, C., Tookey, J. E. \& Sommerville, J. 2011. Logistics simulation modelling across construction supply chains. Construction Innovation, 11, 212-228.

Vidalakis, C., Tookey, J. E. \& Sommerville, J. 2013. Demand uncertainty in construction supply chains: A discrete event simulation study. Journal of the Operational Research Society, 64, 1194-1204.

Vivek, S. D., Richey, R. G. \& Dalela, V. 2009. A longitudinal examination of partnership governance in offshoring: A moving target. Journal of World Business, 44, 16-30.

Voss, C. 2009. Case Research in Operations Management. In: Karlsson, C. (ed.) Researching Operations Management. New York: Routledge.

Voss, C., Tsikriktsis, N. \& Frohlich, M. 2002. Case research in operations management. International Journal of Operations \& Production Management, 22, 195-219.

Wacker, J. G. 1998. A definition of theory: research guidelines for different theorybuilding research methods in operations management. Journal of Operations Management, 16, 361-385.

Wilkins, A. L. \& Ouchi, W. G. 1983. Efficient Cultures: Exploring the Relationship Between Culture and Organizational Performance. Administrative Science Quarterly, 28, 468-481.

Williamson, O. E. 1979. Transaction-Cost Economics: The Governance of Contractual Relations. The Journal of Law and Economics, 22, 233-261.

Williamson, O. E. 1999. Strategy research: governance and competence perspectives. Strategic Management Journal, 20, 1087-1108.

Williamson, O. E. 2008. Outsourcing: Transaction Cost Economics and Supply Chain Management. Journal of Supply Chain Management, 44, 5-16.

Winch, G. M. 2001. Governing the project process: a conceptual framework. Construction Management and Economics, 19, 799-808.

Yin, R. K. 2014. Case Study Research: Design and Methods, Thousand Oaks, California, SAGE Publications, Inc. 
Ying, F., Tookey, J. \& Roberti, J. 2014. Addressing effective construction logistics through the lens of vehicle movements. Engineering, Construction and Architectural Management, 21, 261-275.

Yuchtman, E. \& Seashore, S. E. 1967. A System Resource Approach to Organizational Effectiveness. American Sociological Review, 32, 891-903.

Zajac, E. J. \& Olsen, C. P. 1993. From Transaction Cost to Transactional Value Analysis: Implications for the Study of Interorganizational Strategies. Journal of Management Studies, 30, 131-145.

Zeng, A. Z. \& Rossetti, C. 2003. Developing a framework for evaluating the logistics costs in global sourcing processes. International Journal of Physical Distribution \& Logistics Management, 33, 785-803. 


\section{Papers}

The papers associated with this thesis have been removed for copyright reasons. For more details about these see:

http://urn.kb.se/resolve?urn=urn:nbn:se:liu:diva-147831 